University of Nebraska - Lincoln

DigitalCommons@University of Nebraska - Lincoln

University of Nebraska Press -- Sample Books

and Chapters

University of Nebraska Press

Spring 2010

\title{
A Doctor among the Oglala Sioux Tribe
}

Robert H. Ruby

Follow this and additional works at: https://digitalcommons.unl.edu/unpresssamples

Part of the Arts and Humanities Commons

Ruby, Robert H., "A Doctor among the Oglala Sioux Tribe" (2010). University of Nebraska Press -- Sample Books and Chapters. 73.

https://digitalcommons.unl.edu/unpresssamples/73

This Article is brought to you for free and open access by the University of Nebraska Press at DigitalCommons@University of Nebraska - Lincoln. It has been accepted for inclusion in University of Nebraska Press -- Sample Books and Chapters by an authorized administrator of DigitalCommons@University of Nebraska - Lincoln. 
A Doctor among the Oglala Sioux Tribe 


\section{A Doctor among the 0glalasioux Tribe}

The Letters of Robert H. Ruby, 1953-1954

Robert H. Ruby $\mid$ Edited and with an introduction by Cary C. Collins and Charles V. Mutschler 
(C) 2010 by the Board of Regents of the University of Nebraska. All rights reserved. Manufactured in the United States of America.

Publication of this volume was assisted by The Virginia Faulkner Fund, established in memory of Virginia Faulkner, editor in chief of the University of Nebraska Press.

Library of Congress Cataloging-inPublication Data

Ruby, Robert $\mathrm{H}$.

Doctor among the Oglala Sioux Tribe: the letters of Robert H. Ruby, 1953-1954 / Robert H. Ruby; edited and with an introduction by Cary C. Collins and Charles V. Mutschler. p. cm.

Includes bibliographical references and index.

ISBN 978-0-8032-2625-8 (cloth : alk. paper) 1. Oglala Sioux Tribe of the Pine Ridge Reservation, South Dakota-History2oth century. 2. Oglala Indians-South Dakota-Pine Ridge Indian ReservationSocial life and customs-2oth century. 3. Community life-South Dakota—Pine Ridge Indian Reservation-History-2oth century. 4. Oglala Indians-Medical care-South Dakota—Pine Ridge Indian Reservation-History-2oth century. 5. Ruby, Robert H.-Correspondence. 6. Physicians-Nebraska-Pine Ridge Indian Reservation-Correspondence. 7. Whites—Nebraska-Pine Ridge Indian Reservation-Correspondence. 8. Pine Ridge Indian Hospital (S.D.)—History2oth century. I. Collins, Cary C.

II. Mutschler, Chas. V. (Charles Vincent), 1955- III. Title.

E99.O3R79 2010

978.004' $975244-\mathrm{dc} 22$

2009039102

Set in Minion by Kim Essman. 


\section{Contents}

List of Illustrations . . . . . . vi

List of Maps. ........... vii

List of Figures . . . . . . . viii

Acknowledgments .........ix

Introduction:

The DeadliestWar .........xi

Timeline of Selected Events in the

Life of Robert H. Ruby, MD . . . lxv

Editors' Comment on Editorial

Methodology............ Ixix
1. August 1953 . . . . . . . . . . 1

2. September 1953 .........22

3. October 1953 . . . . . . . . 35

4. November 1953 . . . . . . . . 49

5. December 1953 . . . . . . . 6 67

6. January 1954 . . . . . . . . 78

7. February 1954 . . . . . . . . .100

8. March 1954 ........... 132

9. April 1954 . . . . . . . . . . 154

10. May 1954 . . . . . . . . . . . . 174

11. June 1954 . . . . . . . . . . 204

12. July 1954 . . . . . . . . . . . .220

13. August 1954 . . . . . . . . . . 243

14. September 1954 . . . . . . . 274

15. October 1954 ........ 300

16. November 1954 . . . . . . . . 313

17. December 1954 . . . . . . . 320

Editors' Postscript. . . . . . . . 324

Appendix...............327

Notes ..................329

Bibliography ............ 345

Index ...............351 


\section{Illustrations}

following p. 112

Street scene, Pine Ridge, South Dakota, ca. 1940 s

Street scene, Pine Ridge, South Dakota, ca. 1940s

Pine Ridge Hospital

Dr. Ruby's house, September 1953

Dr. Ruby in his U.S. Navy uniform, with Captain, July 1954

Dr. Ruby and daughter, Edna, 1954

Dr. Ruby in front of the new Pine Ridge Hospital, June 23, 2006

Charlie Yellow Boy, Edna Ruby, and Jeanne Ruby, Pine Ridge, 1954

Dr. Ruby on the front steps of Pine Ridge Indian Hospital, 1954

Lillian and Lawrence Mickelson with Edna Ruby, Pine Ridge, 1954

Typical reservation housing, near Manderson, South Dakota, 1954

White Coyote with team and wagon, 1953

Dr. Ruby outside their home in Pine Ridge, South Dakota, July 1954 


\section{Maps}

1. Robert Ruby's Northwest . . . .lxxi

2. Washington State........ lxxii

3. South Dakota .......... Ixxiii

4. Indian Reservations in southwestern South Dakota ...... lxxiv

5. Pine Ridge Indian Reservation and Environs .......... lxxiv 


\section{Figures}

1. Native American Church meeting altar arrangement. . . . . . . 184

2. Lacing pattern for drum used in "peyote service" ...........187

3. Native American Church meeting altar arrangement. ........233

4. Message to Great Spirit at Yuwipi service......... 268 


\section{Acknowledgments}

First and foremost, thank you to Dr. Robert H. Ruby for his willingness to allow us to publish his letters, which had been stored away for decades in the bottom of a cabinet in his home in Moses Lake, Washington. For several years we had been working with Dr. Ruby on historical projects related to his life, his writing career with his long-time coauthor John A. Brown, and Pacific Northwest Indian and white relations generally. In the course of our collaborations, Dr. Ruby frequently mentioned that he had been the head of the hospital on the Pine Ridge reservation and that he had written extensively about his service there. What he had composed were letters addressed to his sister, but when he spoke of his correspondence he often referred to what he called his "Pine Ridge diary." Like curious historians are inclined to do, we began asking him about the nature of his documentation. Initially Dr. Ruby shrugged off the importance of the letters, and our conversations with him really did not go very far. But we were persistent, and eventually he agreed to locate and share the letters with us.

The fact is that so much time had elapsed since Dr. Ruby had last looked at the letters (nearly a half century), he retained only a vague recollection of what was specifically contained in them, and, like us, he was startled to discover their elaborate and detailed descriptions of the functioning of the hospital and the overall state of affairs on the Pine Ridge reservation in the middle 1950s. The letters also revealed the story of Dr. Ruby and his late wife's experiences and the at once tragic and inspiring circumstances of the Oglala Sioux Tribe. Over time we came to believe that the letters were far too valuable to be stuffed back into 
that cabinet where they were likely to remain until someone at some point (and unthinkably to us historians) simply disposed of them. So the decision was made to edit them for publication. In guiding that process through to completion, we are grateful to the editors of the University of Nebraska Press for their receptive response and their immediate and sustained enthusiasm. We are also deeply indebted to the expert assistance and unflagging good cheer extended by Rose Krause, archivist extraordinaire at the Northwest Museum of Arts and Culture in Spokane, where Dr. Ruby's extensive collection of personal papers is housed. We thank Benjamin Reifel's daughter, Loyce Reifel Anderson, for her generous assistance in providing information about her father. At Pine Ridge we were assisted by Cheryl Hemingway, who shared with us rare family photographs of Pine Ridge, and Lisa Schrader-Dillon of the Oglala Sioux Tribe, who gave us an extensive tour of the still-standing old hospital building. Joe Svara grew up on the Pine Ridge reservation and from 1948 to 1957 owned and operated Joe's Market in Pine Ridge. Joe now lives in Sturgis, South Dakota, but met us in Rapid City to share his memories. Father Peter Klink, ss, president of Red Cloud Indian School (formerly Holy Rosary Mission), spent an afternoon filling us in on current conditions on the reservation. After all these years still a resident of McCall, Idaho, Dr. Ruby's sister (and the recipient of his letters), Marion Johnson, was always helpful and a delightful traveling companion (along with Dr. Ruby, she accompanied us to Pine Ridge), while closer to home we thank our families for their love, perseverance, and understanding: Cary's wife, Tina, and sons, James and Nick Collins, and Charlie's mother, Denise Mutschler. 


\section{Introduction}

The Deadliest War

They drove throughout the day and into the evening, their unlikely destination Pine Ridge, South Dakota. It could be said "unlikely" because they had been married for only a couple weeks and to this point in their relatively young lives could claim absolutely no affiliation with either the Pine Ridge Indian Reservation or the members of the Oglala Sioux Tribe who lived there. It was August 1953, and Robert Ruby was a thirty-two-year-old U.S. Public Health Service surgeon assigned to Pine Ridge Indian Hospital. His bride, Jeanne (pronounced “Jean”), was three years younger than him and already a seasoned teacher of home economics. She had taught in several rural school districts in eastern Washington State. Together Robert and Jeanne had stuffed their belongings into their late-model olive green Pontiac coupe, scooped up their rascally black-and-white collie puppy, Captain, and pulled out of the driveway of Jeanne's mother's house in Chelan on the upper Columbia River. Although they could not have known it, they were setting off on a journey that in many ways would pave the way for the remainder of their lives. ${ }^{1}$

Even their first hours on the road were highly symbolic. On a hill, at a historic spot just above where the two-lane asphalt began to bend down into the majestic steep incline of White Bird Canyon on the River of No Return in west central Idaho, the Rubys edged over onto the shoulder of Highway 95. On this hallowed ground, near the site of the first major military engagement of the Nez Perce Indian War of 1877, they pitched camp. Robert and Jeanne prepared and ate a simple picnic dinner, rolled out sleeping bags, and passed a peaceful night with one 
sky above them. From White Bird Canyon, the Rubys resumed their flight into the future. For a couple days they delayed in McCall, Idaho, visiting with Robert's sister, Marion, her husband, and their children. Then, two days later, Robert and Jeanne were in Aberdeen, South Dakota. Robert had been directed to report to the Area Office of the Bureau of Indian Affairs (BIA) there for an orientation meeting. Once that tedious chore was out of the way, Robert and Jeanne headed out again. Pointing their Pontiac in a southwesterly direction, they were within hours catching their initial glimpses of their new home, their first home together. ${ }^{2}$

For the next year and a half the Rubys lived, labored, and learned on the Pine Ridge Indian Reservation. From the outset-and for the duration of their residency there-little seemed to go as planned. Robert had assumed he would be holding a staff position, but to his utter astonishment he was immediately named the hospital's medical officer in charge, a powerful administrative post that encompassed an extensive range of supervisory and bureaucratic responsibilities. Circumstance unfolded unexpectedly for Jeanne as well. She had thought her duties would be confined to concerns of home and family, but when a vacancy opened up in the government boarding school on the reservation, she reluctantly accepted the position of classroom teacher. It was in these ways then, within the orbit of their professional obligations and relationships, that the Rubys came to be looked at as important, recognizable public figures on the Pine Ridge reservation. On almost a daily basis they engaged in significant, meaningful interactions with the American Indian population, holding jobs, rendering services, and making decisions that directly impacted the Oglala Lakota people they were there to serve. ${ }^{3}$

The eighteen months spent by the Rubys in Pine Ridge, however, are noteworthy for another reason that could scarcely have been imagined in 1953 by anyone other than possibly Robert Ruby. From the very first days after he and Jeanne arrived on the reservation, he entered into an extensive, uninterrupted correspondence with his sister back 
in McCall. Diarylike, comprehensive, and candid, the letters that Robert wrote wove a profoundly revealing, personal accounting of reservation life at midcentury and, when assembled and presented as a cohesive document as they are here, deliver a memoirist's treatment of Ruby's experiences: what he saw and how he felt and reacted. Sweeping, frank, and insightful and crafted with the intimacy and sophistication that only a BIA insider could have, Ruby's letters described the massive, diverse, and complicated role that the government bureaucracy was continuing to play in the lives of the Oglala Lakota people into the 1950 s and, perhaps more significantly, the ways in which the Native population was in turn negotiating and, as best as they were able, using the federal establishment to satisfy their own individual and collective needs and objectives.

Ruby's writings are informative from many perspectives. First, they provide a rare, first-person narrative of Indian health care, a critical and largely unexplored aspect of Indian and white relations in the twentieth century. The position Ruby held as medical officer in charge propelled him to the forefront of the most visible federal presence on the reservation. Pine Ridge Hospital functioned as a hub of community life where the most modern expressions of American society frequently intersected, and sometimes clashed, with those considered the most traditional and ancient. But in whatever guise, the hospital was more than anything a healing place where in Ruby's hands rested, both literally and figuratively, the physical well-being of the Oglala Lakota people.

As medical officer in charge, Ruby also assumed control over a sweep of programs and services that required his constant attention and supervision. Collectively these commanded appropriations that annually swelled into hundreds of thousands of dollars and employed a workforce that numbered among the largest on the reservation. It is not exaggeration that, other than the two positions of agency superintendent and superintendent of schools, the office that Ruby occupied was the most important and far reaching at Pine Ridge. The office, bringing him repeatedly into contact with the superintendent of the agency as 
well as with each of the other fifteen department heads that comprised the BIA administrative team, was the basis of collegial associations and interactions that privileged him with information and knowledge to which few others had access.

Second, Ruby proved an astute observer of people and cultures. Oglala Lakota history, traditions, and ceremonies intrigued and even mesmerized him, and he expended considerable time and energy documenting, often in exquisite detail, what he heard and saw. He traveled over the reservation and the region endeavoring to gain a sense of the place. In doing so, he sought out and befriended numerous members of the Oglala Lakota community, many of whom he interviewed, recorded, and photographed. In this regard Ruby initially found the Oglalas reticent and withdrawn in their interactions with him and, for that matter, with non-Indians generally. He made it a point, however, to try to set them at ease. Notably, he and Jeanne became the first agency employees to have Indians in their home socially, an act of uncommon hospitality and kindness that in addition to Jeanne's teaching and Robert's health care, helped win their confidence. It also drew the Rubys closely into association with many of the most prominent members of the tribe, those, for example, of the Red Cloud, Black Elk, and Standing Bear families - the children and grandchildren of those Oglala Lakota luminaries of the same name.

Third, Ruby's observations open a window onto the harsh socioeconomic conditions against which the Oglalas were constantly battling. For many tribal members, survival, even at a most meager level, posed a precarious proposition. Pine Ridge projected dolorous images of grinding poverty. The annual per capita income of the Oglalas ranked among the very lowest in the nation, and a vast majority of the reservation's inhabitants were eking out nothing more than bare existence. A large number were living in crudely constructed log shacks, and some only in tents-a deplorable state of affairs that was affording them almost no protection from the extreme climate, which could range from blistering summer heat to arctic winter cold. In addition, 
crime and alcoholism were rampant. Although federal law prohibited the selling of intoxicants on the reservation, several taverns located just two miles south across the Nebraska state line in Whiteclay, operated without restriction. Finally, the reservation appeared astonishingly out of step with modern industrial society. Few Oglalas owned cars and, exactly at the moment when the interstate highway system was beginning to fan out across the nation, horses and horse-drawn wagons remained visible sights at Pine Ridge. In sum, the reservation was different from anything Ruby had encountered, an always testing, always exacting foreign environment that demanded the best-and considerably more-than he or any public official could have been expected to give. ${ }^{4}$

A fourth reason the Ruby letters are valuable is the historical era that they seek to illuminate. The early 1950 s represents a pivotal though understudied period of American Indian and white relations, a transition between two key phases of federal Indian policy: the Indian New Deal and termination. The former policy (dating from 1933 to 1945), despite its nod to cultural pluralism, tolerance, and revitalization, elicited criticism for tightening the grip of national controls over Indians and reservations. The latter policy (dating from 1945 to 1961) fell from favor for its attempts to scale back federal trust responsibilities. Ruby addressed the debate over these contrasting national prescriptions and what he foresaw as the potential ramifications of each for the Pine Ridge reservation and the Oglala Lakota people. An unintended but inescapable consequence of the Indian New Deal, he came to believe, was the gradual, ever-increasing dependence of the Oglalas upon government programs and services. For Ruby, it was a debilitating, unacceptable erosion of self-sufficiency that compelled him to embrace aspects of the policy of termination. ${ }^{5}$

Fifth, Pine Ridge was then, and it remains so today, among the most recognizable and important Indian reservations in the United States. Having served as a witness to numerous remarkable and tragic events in history, what has transpired there has often been considered the har- 
binger of a deeper story bearing national implications. Ruby recognized the special niche of this place in the collective American psyche, and he sought to reconcile what had happened in the past with what he was experiencing in the present with what he thought might play out in the future. In part, his motivation for writing stemmed from the forward-looking assumption that his observations, if preserved, might someday be of value. He was acting on a conviction that he was capturing snapshots of moments in time that were in jeopardy of being lost and could not otherwise be salvaged or much less reproduced, save through his admittedly imperfect although always tenacious attempts to get them down on paper, tape, and film.

Finally, the published memoirs of BIA officials, particularly those documenting this historical era and subject, number relatively few. By making publicly accessible the writings of Robert Ruby, a contemporaneous voice is added to a historical account that has often had to rely on and has been dominated by government documents and reports. Similarly, they also provide a useful corollary to the plethora of American Indian memoirs, reminiscences, and biographies that have appeared in recent years, offering details, opinions, and interpretations that would have been inappropriate to include in official correspondence. By introducing into the mix the nonofficial writings of federal personnel such as Robert Ruby, a more textured and layered understanding of public policies and programs is made possible as is the construction of richer and more nuanced histories. The result is a better-informed readership.

Robert Holmes Ruby was born on April 23, 1921, in Mabton, Washington. He grew up there on a forty-five-acre farm that bordered the Yakama Indian Reservation. His father raised potatoes and also kept a garden, and when Ruby was a boy it was not an unusual occurrence for Indian people to stop by the family home seeking food. It was in his hometown, slogging as a journalist for his high school and local city newspapers, that Ruby got his start as a writer. What he wrote could boast scant historical content, but the satisfaction that he took 
away from the process of preparing his essays caused him to flirt with the notion of one day becoming a professional newspaperman. However, after graduating from Mabton High School in 1939 and enrolling in Whitworth College in Spokane, it was premed that he chose as his major. Yet his pen remained active. Again Ruby enlisted his services as a reporter, this time for his college newspaper. He had the good fortune of interviewing and writing on such notable public figures as Paul Robeson, Marian Anderson, and Lily Pons. ${ }^{6}$

In three years Ruby's coursework at Whitworth was finished, and he then continued his education by entering the Washington University School of Medicine in St. Louis. The years he spent in the Midwest, preparing for a career in health care, Ruby has noted, were one of only two times in his life that he lived apart from Indians. ${ }^{7}$

Following his graduation from medical school in 1945, the pace of Ruby's life quickened. He wrapped up a nine-month internship in Detroit and was inducted into the U.S. Army Air Corps. For twenty months he served in Denver, Los Angeles, and finally with American occupation forces in Japan. After his discharge in December 1947, he began training as a surgeon. Ruby took a fellowship at the Sugarbaker Cancer Clinic in Jefferson City, Missouri, and completed a year of postgraduate study at Washington University. He then spent four years in pathology and general surgery at a hospital in St. Louis. ${ }^{8}$

But the track that he was on soon veered in another direction. At the outbreak of the Korean War, Ruby was conscripted back into the military. Fortuitously, a clause contained in the Doctor-Dentist Draft Law of 1950 granted physicians their preference of service, and Ruby opted to join the Public Health Service, the government agency charged with supplying doctors to the U.S. Coast Guard, the American diplomatic corps, and the U.S. Indian Service. Visions of hobnobbing in some exotic foreign embassy briefly flashed through Ruby's mind, but when he received his assignment, it turned out to be with the Indian Service. He was given administrative supervision over the Indian hospital on the Pine Ridge reservation. Make no mistake. Pine Ridge was a 
world apart from the likes of a Cairo or Tokyo, but waiting was a lifealtering experience. ${ }^{9}$

In 1953 Pine Ridge was a way-out-of-the-way frontier town of some 1,250 inhabitants, the great majority of whom were American Indian. The village lay on the southern edge of the two-million-acre (an expanse the size of several small states) Pine Ridge Indian Reservation, which sat on the extreme southernmost border of South Dakota. In Ruby's memory, Pine Ridge looked “just like an old western town with beaten-down frame buildings, mostly dirt streets, no sidewalks, and a few streetlights," a stark image that prompted him to remark, "It wasn't pretty." There was one main street, one school, one post office, one tribal agency, two service stations (Hemingway Texaco and Gerbers), two grocery stores (Hagels and Joe's Market), one bank, one variety store (the Pejuta Tepee), one hotel (Gerbers), one barbershop (Salaway's), five churches (accommodating Catholic, Episcopalian, Presbyterian, Methodist, and Church of Jesus Christ of Latter-Day Saints faiths), one state welfare office, and one hospital. There was no tavern, no restaurant, no theater (on weekends movies were shown at Holy Rosary Mission but only for students attending the school), no clothing, hardware, or department stores, no police department (other than the agency tribal police), no fire department, no funeral home (a mortician from the Chamberlain Funeral Home in Rushville, Nebraska, removed bodies, prepared them for burial, and then returned them to the reservation), no Laundromat, no car dealership, no pharmacy (medicines were issued directly to patients by hospital staff), no radio or television stations, no newspaper, no telephone service after 5:00 in the evening (that was when the operator went home), and no public library, swimming pool, or park. The nearest major city was Rapid City, 110 miles to the northwest. The much smaller, though more convenient Chadron, Nebraska, was half that distance to the southwest. In order to procure goods and services unavailable in Pine Ridge, agency employees also frequented other population centers such as Hot Springs, South Dakota, and Gordon and Rushville, Nebraska. ${ }^{10}$

xviii 
Pine Ridge was located on the Great Plains and not in the American South, but elements of de facto segregation governed social relations in the town in a manner similar to that dominant in other sections of the country. In his masterful Blood Struggle: The Rise of Modern Indian Nations, the attorney and historian Charles Wilkinson has described the settlement - the largest on the reservation — as it appeared when Ruby lived there. Pine Ridge was separated into two halves, neither of which seemed to have anything in common with the other. "Highway 18 laid down a line of demarcation," Wilkinson asserted. "The west side was the white side, with the BIA office building, the jail, the BIA boarding school, and housing for federal employees." It was here where the Rubys and most of the hospital staff lived. Meanwhile, the other side of the road presented a different picture. "To the east," Wilkinson continued, "lay a shantytown, home to Indian people, a place devoid of the plumbing and electricity that served the community across the highway." In Wilkinson's assessment, neither the reservation nor its Native inhabitants exhibited much of the influence of non-Oglala society. "Many old men in Pine Ridge wore their hair in long braids, Lakota style, but the outlying villages-Porcupine, Wanblee, Yellow Bear, Kyle, Allen, and others-were even more resolutely traditional. Out in the backcountry, families sheltered in tipis, tents, and log cabins lived much as the Lakota had for centuries."11

Casting a long shadow over everything was the BIA. Characterized by Wilkinson as “The Company' in a company town," there was virtually no aspect of reservation life that escaped the sticky reach of this federal agency. "The bureau dominated the economy as employer, purchaser, and consumer. It handed down the laws and ran the police and courts. It controlled the tribe's only economic asset, the fair-to-middling rangelands" and, "far from promoting Lakota interests," leased "vast expanses of grazing land to large non-Indian cattle companies at rates well below market value." Each district on the reservation was assigned a subagent who controlled almost every move. The permission of these functionaries, known as boss farmers, was necessary for 
an Oglala farmer to as much as sell a cow. Even more restricting was the fact that all lease payments had to be sent directly to the BIA, which in turn paid Oglala property holders not in cash but in vouchers, a procedure that in essence required the Indians to justify how they were spending their own money. ${ }^{12}$

Equally powerful were cultural and social repressions. In schools, both those operated by the BIA and ones under church supervision, children were immersed in the precepts of Christianity, but at the neglect of their traditional Oglala beliefs. And that was only one area of socialization. Students were prohibited from speaking their Lakota language, their braids were cut, and all Native life ways were denigrated as "pagan and savage." When something as seemingly benign as the sound of drumming wafted through the reservation, school instructors informed their impressionable charges that what they were hearing was "devil worship." Another example was the suppression of Sun Dance. The most important and enduring Oglala Lakota ceremony, having been banned since 1881 and driven underground by the BIA, Sun Dance was finally restored and allowed to be practiced publicly in the early 1950s. But as Wilkinson pointed out, it was only "under tightly controlled circumstances." Piercing, he related, was not permitted until the late 1950s, and even then strictly "upon certification from the BIA in Washington." 13

Through all this, however, the Pine Ridge reservation remained the embodiment and keeper of the Oglala Lakota's most cherished possession. The vigilant guardian of their traditions, culture, and past and the basis and bedrock of their tribal sovereignty, it was as valuable as life, a bulwark that had enabled the Oglala Lakota to withstand the strongest assimilationist assault thrust against them. This vital sustainer of all things, timeless and with no beginning and no end and the very marrow of their existence, was their land. Ruby's letters reveal and lend weight to Wilkinson's apt assertion: That this place was so much more than the barren wasteland that often met the gaze of the traveler just passing through. For the Oglala Lakota the reservation, in all its man- 
ifestations, was simply the familiar they knew as home. As Wilkinson poignantly wrote, "To the Sioux, the reservation was the setting for the tribe's long history, the tragic and the uplifting and the ordinary, the place where all the ancestors had been buried in ceremony, the locale for all of Grandfather's stories. The land was a broad, ever-present charter-writ in sky and flowing grass, in low hills and cottonwood hollows and piney ridges_ — of freedom from the difficulties of daily life. Even the Badlands of the northern part of the reservation, a rough, choppy, eroded-out terrain of gullies and buttes, carried Lakota memories and were home to scattered families on plots far from any road." 14

It was against this backdrop that Robert Ruby accepted administrative responsibility over the Pine Ridge Hospital. At the time he embarked upon his duties, he knew very little or absolutely nothing of the issues and problems articulated by Wilkinson, of the Oglala Lakotas and their history and culture, of the terrible trials that simultaneously burdened and challenged their survival. All this had to be learned, and to Ruby's credit, he did learn. With enthusiasm and energy, he immersed himself in the reservation and its people. As he elevated them as his foremost interest and priority, he seized on almost every encounter as an opportunity to increase his knowledge and understanding. Part of what Ruby came to realize was that at Pine Ridge he had been appointed to, and assigned administrative control over, a hospital and a health care system that were the products of complex and substantial histories, ones that had been a full seventy-five years in the making and were an integral component of the even longer and more complicated relationship that existed between the Oglala Lakota and the United States government. ${ }^{15}$

Morning for Indian health care in America emerged out of a most virulent night. The first formal attempt of the federal government to provide services dates to 1832. That year Congress appropriated moneys to purchase and administer smallpox vaccine. Missionaries active in Indian country also attended the sick, a few doctors were hired and assigned to agencies, and army personnel were employed. In the main, 
however, those pioneering efforts proved insufficient, irregular, and poorly coordinated, an ill-defined and incoherent pattern that, at least in the near term, persisted. In 1873 the BIA established a Medical and Education Division but then proceeded to dismantle the medical arm only four years later in 1877 . Want of funds was offered as the reason for the reversal, and almost another half-century would pass before a similar administrative bureau was authorized to oversee the health needs of the American Indians. ${ }^{16}$

In a legal sense, federal obligation to furnish Indian people with health care was solemnized in treaties that, among other assumed benefits, promised medical assistance in exchange for cessions of land and land title. Over time the articles contained in treaties were sustained, extended, and bolstered through a succession of legislative acts, judicial decisions, settlements, and agreements. In the early reservation period and after the end of the Civil War the federal government began staffing Indian agencies with physicians who were required to supply their own medicines and attend to patients scattered over immense distances and living on widely separated reservations. In some instances, the accessibility of those doctors was so constricted-in 1874 only about half of the agencies had doctors-that some local agents felt compelled to learn the rudiments of medicine in order to be able to treat minor ailments and respond to emergencies. Perhaps not surprisingly, many reservation boarding schools, some entrusted with the well-being of scores of students, operated without the benefit of any medical supervision, and it is worth noting that in 1900 only eighty-three physicians were serving the entire American Indian population of the United States and its territories. ${ }^{17}$

Substantial federal support for developing a comprehensive and systematic system of Indian health care was marshaled in the activist term of Commissioner of Indian Affairs Thomas J. Morgan. Although Morgan has been the target of no small battery of criticism leveled by historians for what many contended were his heavy-handed tactics in carrying out federal policies of assimilation, he was an outspoken pro- 
ponent of securing basic medical care for all Indians. In fact, their acceptance of modern treatment methods was perceived by Morgan as incontrovertible evidence of their acculturation. To him, those were the parts of a piece, the one a verifiable measure of the other, a potent symbol of Indians' evolution out of so-called barbarism and into civilization. “The Indian 'medicine' men are ignorant, superstitious, sometimes cruel, and resort to the most grotesque practices," Morgan proclaimed. "The only rational medical treatment comes not from among themselves, but is that which is furnished by the Government physicians." 18

Morgan was not the first commissioner of Indian affairs to have taken up the mantle of Indian health care. In fact, his two immediate predecessors "sought to develop criteria for a more professional medical corps." However, according to the historian Robert A. Trennert, who has written extensively of developments on the Navajo reservation, their initiatives and proposals for reform sounded better than they were in practice, whereas Morgan managed to achieve tangible, quantifiable results. ${ }^{19}$

In 1890 the commissioner spearheaded a lobbying campaign to create an office of medical supervisor. As he envisioned the major tenets of the position, management of the health of the American Indian population would reside with this official as would the duty of formulating a ledger of qualifiers and job descriptors for the employees of the Indian medical field service. When Morgan submitted his ideas, no such all-encompassing administrative post existed within the federal bureaucracy. "This very important branch of the service is without competent supervision," Morgan decried shortly after he assumed office. "There is no professional head. The supervisor of the medical service should require the entire time of a competent expert." ${ }^{20}$

Troubling to the commissioner was the lack of uniform, prescribed official requirements and carefully crafted best practices in force regulating the hiring and monitoring the performance of medical personnel. Rather than approved criteria and clearly enunciated departmen- 
tal policies and guidelines guiding decisions, the quality and expertise of staff was mostly left to chance. On the positive side, Morgan felt certain that "Many of the men ... serving as physicians" were "of high personal character, of good professional attainment and experience," and faithful in the "performance of their duties." Unfortunately, those were traits not shared by all. In other instances, for reasons as serious as "immorality, neglect of duty, incompetency, or unprofessional conduct," Morgan had found it necessary to dismiss doctors from the medical branch. He was quick to point out, however, that under his watch care had been taken to have their places filled with individuals considered "trustworthy and competent." 21

In Morgan's eyes, the most glaring deficiency in the hiring practices of the BIA was the absence of a formal assessment to quantify the competency of applicants. The process in place, as he discovered when he took office, obligated doctors only "to produce a diploma from some reputable medical school and to submit testimonials as to moral character and correct habits." The degree stipulation had been in effect since 1878, but from Morgan's perspective, it constituted a slight advancement. "Their appointments," he asserted, were "not guarded with that care which the nature of the services required of them demands." Morgan believed that rigorous standards needed to be devised, adopted, and followed. "No one should be appointed except upon an examination as to his health, his professional attainments, and his moral qualifications," the commissioner declared. "In addition to his qualifications for general practice, his ability to give instruction on hygienic subjects to school pupils should be tested, and he should possess such scientific and practical knowledge as will prepare him to have an oversight of the entire sanitary conditions of a whole tribe. In short, he should be capable of being a health officer as well as a physician and surgeon."22

To amplify the challenges of the reservation physician, Morgan contrasted the duties and requisite compensation of Indian Service personnel with that of their counterparts serving in the army and navy. What he found was disturbing. Compared to the American soldier, the 
American Indian was receiving substantially less in the way of federal support for health care. For example, in the army and navy in 1890, 352 surgeon-physicians - this was how they were labeled-were treating a combined military force of 36,694. The Indian Service, meanwhile, employed 82 surgeon-physicians caring for a national Indian population set at 180,184. As one might suppose, the patient load carried by medical personnel depended upon the branch of service to which one belonged. On average, the army surgeon-physician was treating 137 patients annually, the navy surgeon-physician 72 patients, and the Indian Service surgeon-physician a staggering 830 patients. Salaries told a similar story. Surgeon-physicians assigned to the army and navy earned an average yearly wage of about $\$ 2,700$, compared to the Indian Service surgeon-physician's $\$ 1,028$. In total, almost one million dollars was appropriated in 1890 to the army and navy for medical purposes whereas the Indian Service received a sum of $\$ 84,300$. Those amounts equated to $\$ 21.91$ spent on each army patient, $\$ 48.10$ on each navy patient, and a paltry $\$ 1.25$ on each Indian patient. ${ }^{23}$

To address some of these jarring inequities, Morgan submitted a blueprint that he hoped would "bring medical aid within the reach of all Indians." To delay or fail to act on his recommendations, the commissioner warned, was to leave "thousands of Indians at these agencies ... utterly unable to have medical care when necessary." Morgan couched his efforts as an attempt to stem "a large degree of needless suffering" and prevent "hundreds of deaths." His plan called for a thorough examination of those candidates applying for government medical positions and the payment of competitive salaries to those meeting the qualifications for and accepting employment. His proposal aimed to eliminate political considerations as a factor in making appointments, substituting the operational principle of "for cause" as the only basis for retaining and terminating employees. In addition, Morgan wanted a hospital "connected with every boarding school" and "at every large agency a general hospital for the severe cases of illness that require treatment which can not be given at the homes." Finally, 
so they could begin working professionally among their own people and holding up Charles Eastman, Carlos Montezuma, and Susan La Flesche as three individuals who had graduated from medical school and then gone on to successful practice, Morgan urged training Indians as doctors and nurses. ${ }^{24}$

Those ameliorating steps notwithstanding, Morgan anticipated a tough road ahead, at least in the near term. Militating against quick returns was an overwhelming demand for services counterbalanced against a grudging level of support seeping out of the Indian Bureau in Washington DC. Medical personnel worked grueling hours under the most challenging circumstances for subpar pay. "The duties devolving upon the physician are very severe," Morgan attested. "He has the work of a surgeon and physician, with the sanitary oversight of people with whose language he is unfamiliar and who are ignorant, superstitious, and predisposed to a great variety of diseases. He must be his own apothecary; he usually has no hospital and no nurses, and his patients have few of the most ordinary comforts of home, and little, if any, intelligent care in the preparation of their food or the administering of prescribed medicine. He is alone and has to cope with accident and disease without consultation, with few books, and but few surgical instruments." ${ }^{25}$

As it turned out, Morgan's initiatives were slow to gain traction, a sluggish response that caused the commissioner to ramp up the decibels of his rhetoric. In 1892 he characterized the miserly level of health care being provided to the American Indians as a "national disgrace." In raising the issue with the secretary of the interior again, Morgan called attention to the impossible situation that existed on the Pine Ridge reservation. It was "simply absurd to attempt, with only one physician," he postulated, "to care for the wants of more than 5,00o Indians, scattered over a territory almost as large as Connecticut." Emblematic of the Spartan support simmered a galling reality. Not a single hospital, not at Pine Ridge and not anywhere else in the United States, had been built specifically for the relief of Indians. "There still exists among In- 
dian tribes the same urgent and pitiful need for proper medical attendance and hospital service," Morgan agonized. "Indian reservations have no hospitals and no place to which persons suffering from acute diseases, severe accidents, contagious diseases, or any other physical malady can be taken, and in which they can receive the nursing and care and medical attendance which they sorely need, and which ought to be furnished them in the name of humanity." Lives rested in the balance, Morgan pleaded. "Left to themselves they suffer unnecessarily and miserably perish." The commissioner reminded his superior that "again and again" he had "urged this matter." Estimates for funds had been submitted "which might be used in the establishment of hospitals among Indians." But a tightfisted Congress had failed to approve the appropriations, thereby reducing his most strenuous exertions to nothing and leaving both him and the Indian Bureau "powerless to remedy a great evil." ${ }^{26}$

The vision of the commissioner extended beyond the purview of just hospitals. He pressed for the authorization of a series of "asylums," including "almshouses for the blind, deaf, insane, the incurables, and the aged and other helpless and destitute Indians." In Morgan's opinion, failure to act was tantamount to the United States neglecting to meet its solemn trust obligations to the American Indians. "There is nothing for them," he warned fatalistically, "but neglect, pain and exposure until death ends their sufferings." ${ }^{27}$

In large measure the temporizing hopes of Commissioner Morgan were to be realized in the educational realm of Indian affairs. With the emergence of the off-reservation boarding school movement in 1879, doctors began to be added to the rosters of school staffs, and as the federal Indian education system expanded, appropriations were allocated for the construction of clinics and hospitals. In the early 189os, in no small part as a result of the concerted efforts of Commissioner Morgan, nurses appeared on the federal payroll for the first time, and a field nurse program was inaugurated on reservations. Furnishing Indian families with direct home instruction on the benefits of clean- 
liness, hygiene, and routine doctor's care, field nurses also imparted nutritional advice, homemaking skills, and prenatal care. By the turn of the century, a degree of health care was to be had for most students enrolled in off-reservation boarding schools, facilities such as Carlisle in Pennsylvania and Chemawa in Oregon. In fact, on some campuses separate infirmaries were constructed for the treatment of tuberculosis, a scourge to Indian people and a leading cause of their mortality. In 1909, in conjunction with the efforts underway in off-reservation boarding schools, an office of medical supervisor was added to the Educational Division of the BIA. ${ }^{28}$

On November 2, 1921, Congress approved legislation that was to profoundly impact the future of Indian health care in the United States. Public Law 67-85, popularly known as the Snyder Act, moved beyond anything previously done. Authorizing discretionary appropriations for "the relief of distress and conservation of health" of American Indians and Alaska Natives, funds were earmarked for the benefit, care, and assistance of this targeted group and, as the primary means by which physicians and other medical personnel were to be hired, offered tangible evidence of a more active, direct, comprehensive, and systematic involvement by the national government in this emerging sphere. Under the statutory authority vested in the Snyder Act, members of federally recognized tribes who resided on reservations were declared eligible to receive services and the commitment of the American government to administer the health care needs of Indians appeared beyond question. ${ }^{29}$

The principles articulated in the Snyder Act were augmented in 1924 by the creation of a separate Medical Division under the authority of the BIA and the Department of the Interior. Another change occurred in 1926. That year "physicians from the Commissioned Corps of the United States Public Health Service were first assigned to Indian health programs." This ostensibly remained the status quo until August 5, 1954-although Indian New Deal-era legislation allowed the secretary of the interior to contract with states and territories for equivalent- 
level services_- when the Indian Health Service was formed as a separate agency operating under the Public Health Service and the newly organized Department of Health, Education and Welfare, today known as Health and Human Services. The transition, which created the only national health program in American history for civilians, became official on July 1, 1955, six months after Robert Ruby left Pine Ridge. ${ }^{30}$

The introduction of health care to the Oglala Lakota living on the Pine Ridge reservation suffered through the same fits and starts characteristic of the national scene. In 1878, shortly after Red Cloud Agency on the North Platte River in eastern Wyoming was removed to its present location on White Clay Creek in South Dakota and reconstituted there as Pine Ridge Agency, health care came to represent a gradual but ever-growing focus of the local federal bureaucracy. To varying degrees, and sometimes with considerable overlap, tribal members received services through one of two government entities: the agency physician and the physician assigned to the boarding school at Pine Ridge. Often the same person occupied both positions, and from almost the outset the level of need far outweighed the ability, or the willingness, of the national government to meet the health requirements of the Oglala Lakota people. For several decades after the relocation of the agency, and up until the time when Ruby served as medical officer in charge, agents, inspectors, and doctors kept up a relentless drumbeat for increased appropriations, additional personnel, and improved facilities.

In terms of medicine and care, the early 1890s-those formative years in which Commissioner Morgan sat in office-represented flush times in the development of the village of Pine Ridge. During that period physicians were hired, a hospital was constructed, methods were standardized, and services were expanded. But at least one government official expressed grave concerns about the location of the agency and the benefits it could offer for healthful living. Chas. G. Penney, the agent assigned to the reservation, advised the commissioner of Indian affairs of a series of factors that he believed could deleteriously impact the quality of life of the Oglala Lakota people. Foremost among 
those were diseases borne of water and sewerage. "The question of water supply and house drainage must also receive immediate attention, if the location of the agency is not changed," Penney wrote. "For many years people have lived here in numbers, making quite a goodsized village, and absolutely without any attention to the laws of health. The whole ground is honey combed with privy vaults and cess pools, abandoned and in use, and the earth is reeking with filth, covered and out of sight, but none the less certain to do its deadly work as soon as the wells shall be contaminated. A pestilence is sure to follow, sooner or later, [on account of] persistence in this violation of the common laws of sanitation." ${ }^{31}$

From a federal perspective, another threat to the health of the Oglala Lakota was the tenacity of traditional methods of healing among them. Shamans_-symbols of "barbarism personified" in the words of Pine Ridge Indian agent V. T. McGillycuddy—were active both during and after the Ruby era, but in the late nineteenth century they posed a substantial obstacle, or at least that was the perception. In August 1884 agency physician J. Ashley Thompson attributed "the large ratio of mortality ... among children ... to exposure and the harsh practices of their relatives, a majority of whom have not the remotest idea of the indispensable [necessity of] nursing and ordinary hygiene; hence it is, [that] many reliable prescriptions fail to benefit and they [that is, the patients, ultimately] return to their medicine men." ${ }^{32}$

Thompson's sense was that the Oglala Lakota did not "enjoy immunity from sickness any more than other races." However, so "wedded to the pernicious influence of the medicine men" were they and so often were those "empirics" encountered in the course of Thompson's daily rounds that he was prompted to conjecture that a "brief sojourn" in Pine Ridge would "impress one with a belief that they were nearly all-men and women —of that vocation." ${ }^{33}$

Thompson, partly due to the presence of shamans but also because of a general paucity of medical knowledge prevalent among the Indians, considered his duties onerous. The Oglalas' maladies ranged from 
"simple constipation to 'misery all over," he reported. "Tubercular diseases, diseases of the digestive system, of the respiratory organs, of the eye, and of the skin (the latter in great variety), of more or less gravity," were presented to him daily for treatment. In one sense, Thompson felt gratified. In most instances it had been possible for "routine treatment" to be applied. But things did not always go so well. He bemoaned that the Oglalas, after receiving their medicines, were usually never heard from again "for months, if ever, so little" did they comprehend "the necessity of systematic treatment." 34

To alleviate some of the burden of laboring as a single physician responsible for the welfare of potentially thousands of patients occupying a vast geographic area and many exhibiting a pronounced aversion to his services, Thompson requested that he be furnished with at least one of the following: "an apothecary, an assistant physician, or limited hospital accommodations - about 10 beds - for such of the sick or injured who come ... to the agency for treatment, and have to return [home] forthwith without receiving material benefit in one visit, because at present there is no provision for shelter and sustenance of the sick." 35 Thompson's recommendations were not immediately acted upon, but definitive steps toward addressing some of them were not to be long in coming.

Much of what is known of the earliest days on the Pine Ridge reservation, particularly those issues related to the budding field of health care, derives from the writings of Charles Eastman. A mixed-blood Santee Sioux from Minnesota, Eastman played a pivotal role in treating survivors in the aftermath of the Wounded Knee Massacre. Educated in medicine at Boston University, he served from 1890 to 1892 as the government physician at Pine Ridge Agency and, in an autobiography entitled From the Deep Woods to Civilization (1916), described the spare, crude structures he encountered in his inaugural assignment as medical officer in charge and his experiences caring for the Oglala Lakota people. In comparing the observations of Eastman to those of Ruby, it seems that in some respects time stood still at Pine Ridge. Eastman, in 
phrases reminiscent of those that would be echoed six decades later by Ruby, soberly recalled his initial impressions of his new station: "Pine Ridge Indian agency was a bleak and desolate looking place in those days," he reminisced, "more especially in a November dust storm such as that in which I arrived from Boston to take charge of the medical work of the reservation." 36

Eastman was one of the first American Indian doctors hired into the Indian Service and was the same age, thirty-two, as Ruby when he located to Pine Ridge. Self-described as "athletic and vigorous, and alive with energy and enthusiasm," Eastman found himself thrust into an environment that tested those qualities. After reporting to the Indian agent for duty, he was escorted to his quarters, which, he discovered, consisted of a bedroom, a sitting room, an office, and a dispensary all arranged in a single long barrack that adjoined the police quarters and the agent's offices. As remembered by Eastman, this was a "flimsy onestory affair built of warped cottonwood lumber" that allowed the "rude prairie winds" to whistle "musically through the cracks." The trappings were austere. "There was no carpet, no furniture save a plain desk and a couple of hard wooden chairs," Eastman wrote, "and everything was coated with a quarter of an inch or so of fine Dakota dust." ${ }^{37}$

Eastman stepped up to the challenges set before him. To help him "in cleaning and overhauling" the premises, he engaged the services of an Oglala woman. He then shifted his attention to the real work at hand. His first order of business was sealing a hole in the wall through which his predecessors had dispensed medicines. Previous doctors, rather than examining patients from inside the barracks, preferred doling out sundry "pills and potions to a crowd of patients standing in line." Eastman, in contrast, hung a sign outside the entranceway that in carefully printed bold letters invited the Oglalas to come inside. ${ }^{38}$

His busiest time, Eastman recounted, occurred during a remarkable reservation-wide event known as the "Big Issue," in which the usually staid village of Pine Ridge was transformed into a "veritable 'Wild West."” For the Big Issue, thousands of Indians either walked or rode in from 
across the reservation in order to receive their bimonthly distribution of government annuities and rations. Eastman painted a colorful portrait of the chaotic scene that invariably played out on the streets and inside the enclosed structures of Pine Ridge. Scores of patients were seen, and medicines were handed out "as if from a lemonade stand at a fair." In the course of his first Big Issue, Eastman learned firsthand of the Oglalas' penchant for self-diagnosis and their proclivity for self-prescribing their own "particular drug or ointment," their favorite being "a mixture of cod liver oil and alcohol." Eastman recalled the surprise of the Oglalas when he insisted upon examining each patient before giving them medicine and their similar response upon realizing that he was able to converse with them "in plain Sioux-no interpreter needed!" Eastman "made a record of interesting cases," noting specifically where the Oglalas were encamped. He intended "to visit as many as possible in their teepees before they took again to the road." 39

Eastman took an abiding interest in the health of the Oglala Lakota, and his unceasing labors on their behalf proved highly rewarding. Soon hundreds of patients were being examined, a daunting caseload that unfortunately sapped Eastman's energies to the point that he eventually deemed it necessary to appeal to the Indian agent for the services of a dispensary assistant and a trained nurse. Included in his petition was a team and buggy, a hospital for the most serious cases, and a house for him to live in. To his surprise, all his requests were granted, and once hired, the dispensary assistant assumed responsibility for putting up "the common salves and ointments, the cough syrups and other mixtures which were in most frequent demand." But, for the most part, Eastman had little to work with. At Pine Ridge there was "no conveyance for the doctor's professional use, and indeed no medical equipment worthy the name." At the agency the "doctor was thrown entirely upon his own resources, without the support of colleagues, and there was no serious attempt at sanitation or preventive work." Out of his own pocket, Eastman purchased many of the needed medical supplies and instruments. ${ }^{40}$ 
Two factors accounted for much of the success that Eastman believed was achieved during his short tenure: his ethnicity and his heartfelt empathy for the members of the Pine Ridge community. According to a contemporary, Eastman managed to forge a formidable reputation that quickly "traveled the length and breadth of the reservation." He imposed "a new order of things" in which equal treatment was received by all and his instructions, which ranged from plain spoken medical advice to complex explanations of "physiology and hygiene," were understood by all. "No Government doctor," it was alleged, had "ever gone freely" among the Oglala Lakota as Eastman did. "[A] good part” of his "days and not a few" of his "nights" were spent "in the saddle," attempting to reach "the most distant parts of the reservation."

By the early 1890 and just over a decade after the creation of Pine Ridge Agency, two hospitals were in operation on the reservation. The first, an appendage of the Oglala boarding school, was available to all members of the reservation community, including students. The second, a field hospital, was set up for those patients who could not conveniently be transported to the hospital connected to the boarding school. The school hospital-interchangeably known as Pine Ridge Hospital and Oglala Boarding School Hospital—was a relatively large three-story structure that had been proposed for construction in November 1889 and began admitting patients almost three years to the day later in November 1892. Featured was a full basement with storerooms and a heating plant, two wards for patients, and an attractive exterior landscaped in lawns, flowers, trees, and cement walkways.

But from the moment of its inception, Pine Ridge Hospital was beset with an inordinate array of problems. For one, the building sat on an isolated, exposed parcel of land that allowed the "cold winter winds" to strike "from all quarters." In addition, the design of the hospital was said to be flawed. It was equipped with only one means of exit, through the front door, and the upper two floors, where the patient wards were housed, had no running water. In fact, all water in the hospital originated from a single source, a faucet attached over the kitchen sink. Even 
greater causes for consternation were a sewage system placed too near the building and a steam plant so inadequate that woodstoves had to be resorted to. Unfortunately, those turned out to be a poor alternative because the large stoves needed "to heat the rooms to a comfortable degree" could not be used without restricting the number of beds in each ward to only two. Finally, space had not been set aside for storing and dispensing medicines, and even the shape of the wards was described as "defective" and "ill adapted to hospital purposes." 42

Such was the imperfect state of repair of this new modern hospital, and administrators struggled to attract and retain personnel. According to J. S. Pede, the first medical officer in charge, "Owing to the incomplete condition of the building, its isolated situation and the meager means for convenience and comfort, but few employes could be found who could be contented with the service in the hospital." Pede commented, "Without exception all the employes constantly complained that the work was too severe and onerous." The exhaustive "climbing up and down the stairs between three floors, the bustle and litter made by two wards full of patients - at one time 19 in number — who bring with them many of the habits of camp life, and who understand nothing of the methods of treating the sick to which they are subjected," he related, "cause the female employes to break down in a short time, with the result that soon their places have to be filled by others." To ease the stress felt by his staff, Pede lobbied for the installation of a dumbwaiter and speaking tubes. ${ }^{43}$

Despite the deficiencies that were plaguing the building, Pine Ridge had been made beneficiary of a mostly functional hospital, one of the first in the Indian Service. In the spring of 1893, when Dr. Z. T. Daniel arrived on the reservation to assume the duties of agency physician, he was able to convey his pleasant surprise at finding "a small hospital here with a full corps of employees." Daniel had worked at Blackfeet Agency in Montana and Green Bay Agency in Wisconsin, and in comparison to Pine Ridge, he judged both of those stations lacking. At Pine Ridge he enumerated a hospital staff that consisted of a stew- 
ard, a matron, a nurse, an assistant nurse, a cook, and a janitor. Two field matrons were assigned to outlying districts, and a field hospital had been established to accommodate those cases that could not be treated in the regular hospital. ${ }^{44}$

But infrastructure was only a single strand in a complex dynamic. Pine Ridge Hospital suffered in other areas as well. Most immediately, the restrictiveness of an institutionalized environment conflicted with the natural rhythms of the Oglalas while the very nature of a hospital setting, especially in terms of symbolism, was not always compatible with Indian customs, values, and beliefs. Daniel, in his annual report for 1894, flagged some of these social and cultural collisions. "Notwithstanding we have an excellent hospital here," he wrote to the commissioner of Indian affairs, "it is difficult to get the Indians into it for treatment." In earlier times the Oglalas "destroyed all buildings and tepees in which a death occurred," Daniel explained, and they held "an aversion to being sick in a house where a corpse has lain." He described the Indians as "intensely social," a characteristic that made them feel imprisoned when cloistered inside the walled rooms and narrow corridors of the hospital ward, where "their visitors are not so numerous, nor are the patient and visitors allowed to gormandize, as is their custom in the camp." Exacerbating Oglala suspicions was their equating of hospital diet to starvation and the ubiquitous rules that tended to govern all human activity: no drumming, no incantations, no singing of songs, no presents received from "sympathizing friends," "no vociferous proclamation of the sickness from tent to tent," and "no wailing by old crooning women which is so sweet to the Indian ear." The hospital, in sum, was "too quiet, too still, too mysterious ... another world." The Indians disliked everything about it, Daniel concluded, with their minds obsessively and unbendingly consumed "on the deaths and failures." Even Oglalas employed at the agency refused to as much as step foot in the building, having affixed to it the eerie moniker of "the dead house." 45

The design of the hospital and its other attendant problems proved 
untenable and required fixing. Therefore the upper floor was completely reconstructed in 1897 and the lower-floor rooms were replastered. With those improvements in place, government inspector James McLaughlin was able to describe the layout of the building that year as "conveniently arranged and neatly kept," relating that the "sick of the reservation, who desire to avail themselves of the privilege, are brought to the hospital for treatment, where every attention possible is given them." However, over the course of his inspection McLaughlin encountered only two employees - the agency physician and his interpreter - a skeleton staff that was impeding the effectiveness of the facility and depriving care from many of those needing it. The inspector recommended hiring three additional employees: another physician, a nurse, and a cook, thereby raising to three the number of doctors on the reservation. In addition to the agency physician working out of the village of Pine Ridge, a doctor at Kyle was assigned to the day schools. The secretary of the interior approved the nurse and cook positions but, citing the prohibitive expense of salaries, declined staffing a third physician. ${ }^{46}$

As one problem inevitably played upon another, the Pine Ridge reservation seemed to operate on the principle of two steps forward and one step backward. Emblematic of that competing inertia was the total destruction of the Oglala boarding school on February 8, 1894, by fire. Mercifully, there was no loss of life, and the hospital building was spared. In fact, patients continued to be admitted-although not children of school age-but in numbers so reduced that in November an inspecting official advised eliminating two of the nurse positions. Apparently the holders of those jobs had "nothing to do but draw their salaries every quarter." ${ }^{47}$

Even so, the medical resources of the reservation were constantly stretched to the limit. In 1894, 825 cases of sickness were diagnosed, treated, or prescribed for. The number of births slightly outnumbered deaths that year: 298 compared to 285 . As reported by Dr. Daniel, tuberculosis and the complications associated with it constituted the primary 
cause of mortality. Asserting that it was practically the only disease contributing to the large death rate, he speculated that the Oglalas might very well in its absence "multiply and overrun the country." To illustrate the lethal nature of tuberculosis, Daniel related the heartrending experience of five Oglalas trained as Episcopal clergymen. After receiving substantial educations to prepare them for a lifetime of ministry service, two of the group had succumbed to tuberculosis. As Daniel described them, "neither were old men"; rather, they were young men "cut off in their prime." Daniel made the rather innocuous assessment that "were it not for tuberculosis," which wrought "such havoc with Indian youth ... the results of their education would be more far-reaching." Regrettably, "in light of this dreaded scourge," he concluded, "no other than a modified pessimistic view" could be "entertained of it." 48

Increasing the susceptibility of Oglala teenagers to tuberculosis was the popularity of cigarette smoking among them. "Any pathologist," Daniel informed the commissioner of Indian affairs, "will tell you of the disastrous effects of tobacco smoke on a pair of lungs predisposed to tuberculosis." To inhale the smoke of cigarettes was "to disseminate the nicotine through the lung tissue," Daniel explained, "which, in combination with the gaseous carbon from the wrapper, produces a depressing, irritating, and biting effect on the delicate organs." It was a "well known" fact, he lectured, "that carbon has a great affinity for oxygen, at high temperatures especially, and the union of carbon from the wrapping of a cigarette with the oxygen in the air cells produces a most poisonous body, known as carbonic acid gas, which will not support animal life." Referencing a practice nearly as pervasive with the children as with the adults, Daniel wanted it made a punishable offense for the Pine Ridge traders to sell tobacco to minors. ${ }^{49}$

In addition to smoking, Daniel linked the prevalence of tuberculosis to two other factors: a ration system that promoted idleness, poor diet, and other undesirable habits and the pervasiveness of intratribal marriage among the Oglalas. "No person can be healthy who does not work, eat well-cooked nutritious food, dress properly and bathe," 
Daniel asserted. It was his observation that "as a rule" the Indians did "none of these things," and therefore they were "sickly," simple as that. To validate his views on what he maintained were the pernicious consequences of marriage between members of the Oglala people, Daniel cited attendance in off-reservation boarding schools and the high incidence of tuberculosis prevalent in those institutions. For Daniel, if children fell prey to disease under ideal conditions-and to him offreservation boarding schools were the epitome of such an environment-then there had to be another explanation for the disproportionate rates of tubercular infection. As he saw it, "Indian children are taken from the high and dry climates of the West, in apparently perfect health, and sent to Carlisle, Hampton, and other Eastern schools, and while there, under the most salubrious surroundings, develop tuberculosis and return to their homes to die, and they do die; they die here, they die in the mountains of Pennsylvania, on the Atlantic coast, in the hills of Alabama, and they will continue to die everywhere they go, of tuberculosis, until the race is so thoroughly crossed by "foreign blood" that it will stamp out the tubercle bacillus, and when that is done the Indian race in its original purity will be no more."50

Daniel favored keeping Oglala children on the reservation to spiriting them away to distant boarding schools where they frequently died or, at the very least, fell victim to some serious physical malady. He hypothesized that "It would be a very interesting study to take all the Sioux children who have been sent to all boarding schools, compute all the money spent on their education, the number who have died, the number who have lapsed into barbarism, or vagabondism, and the number who have really and substantially profited by their learning to the extent of being some service to themselves and to their fellow-men." Injecting his own analysis into what he believed such a study might reveal, Daniel asserted: "Here and there it is granted that some do well, but many would do well anyhow. Some men and women rise to usefulness and eminence in spite of all obstacles, and so will a few Indians, but they will be very few." ${ }^{51}$ 
In the face of his concerns, Daniel rated the overall health of the Oglalas and the medical offerings available to them as "good." Similar to what Ruby would report in the 1950s, he equated the level and quality of services to that which might be "found in the average town." Justifying his assessment, Daniel commented that "while some articles may not be first class, the important drugs are reliable. Within the last three years the medical and surgical supply list has been greatly enlarged and improved." Whereas the quality of water at the agency had been a source of anxiety, Daniel apprised the Indian commissioner that two new tanks had been erected, and because the water that filled them was generated by windmills, it was considered wholesome and safe for human consumption. Oglalas living outside the village of Pine Ridge obtained their water "from brooks and streams, with here and there a well," sources also deemed "healthy, with the exception of containing infusoria," or intestinal parasites. Finally, typhoid bacteria had not been detected, that welcome measure of good fortune a product of the sparse population of the region. ${ }^{52}$

Tuberculosis posed far and away the greatest threat to Oglala health. Figures compiled by James R. Walker, for eighteen years (from July 1896 to May 1914) the government physician at Pine Ridge, exposed a horrifying, unthinkable reality. In the ten-year period that elapsed between 1896 and 1906, 903 full-blood-degree Oglalas and 70 mixed-bloods out of a total reservation population of 5,000 had died of the disease. Based on Walker's statistics, nearly one-fifth of the tribe had lost their lives, an arresting - and relative to the American population as a wholeconsiderably elevated incidence of mortality. Whereas the rate of tuberculosis deaths among the general population of the United States numbered less than two per thousand individuals, the average on the Pine Ridge reservation was eighteen per thousand. ${ }^{53}$

In 1896, Walker's first year in Pine Ridge, W. B. Dew, the day school inspector assigned to the reservation, offered an indication of what the agency physician was up against. "There are many children on this reservation so afflicted with scrofula—having open sores constantly dis- 
charging-as would render them a source of danger to any that come in contact with them," he wrote. Because "the exhalations from these sores soon contaminate the air of the schoolroom," Dew added that it was necessary to have affected students "excluded from school." 54

W. H. Clapp, the acting Indian agent at Pine Ridge, underscored the virulence of the disease. In his annual report for 1899, he attributed to tuberculosis almost all absenteeism experienced in reservation schools. Bemoaning that it was "alarmingly prevalent and in almost every instance quickly fatal," Clapp recounted the tragic fate of several pupils who had passed their physicals the previous September and then had been admitted to the boarding school. Each had since either died or lapsed into "the last stages of this dread disease." Fully one-half of the Oglala tribe, Clapp estimated, was infected. The highest rates were found among the children, and the crisis was growing progressively worse..$^{55}$

Partially responsible were the horrendous living conditions ubiquitous at Pine Ridge. As late as 1910 the reservation continued to struggle with the same issue of sanitation that had been raised by agent Penney some thirty-five years earlier. That year Superintendent James Brennan informed the Indian Office that most Oglalas erected their log houses along watercourses, the same streams and rivers in which they watered their stock, discharged their human excrement, and disposed of their household garbage, but from which they also obtained their drinking water. The consequent level of contaminant prompted Superintendent Brennan to declare that it was "fortunate that these people live in tents much of the time and move about from place to place." He detected a fundamental relationship between the level of environmental pollution and the health of the Oglala people. "Beginning about the first of May in each year and ending in October there is comparatively little sickness among these people," he pointed out, a reality "easily accounted for when we study the Indian life and manner of living. He practically abandons his home during this period and lives an outdoor life. This manner of existing takes him away from [the] filth that is bound to ac- 
cumulate when large families are housed in a single unventilated room during the other months of the year. As soon as their open air life ends and they return to their homes for the winter diseases incident to filth and bad air begin to develop." ${ }^{56}$

The first notable response against tuberculosis at Pine Ridge was mounted by James Walker. In 1896 Walker was forty-seven years old and an eighteen-year veteran of the Indian Service. Having served as a member of the U.S. Sanitary Commission during the Civil War, he was an 1873 graduate of the Northwestern University School of Medicine in Chicago. He had entered into successful private practice in his hometown of Richview, Illinois, but his own health frailties-he suffered from chronic dysentery-dictated him relocating to northern Minnesota, where he subsequently fell victim to hard economic times. In order to provide for his wife and children, he accepted a position with the Indian Service in December 1878. First assigned to the Leech Lake reservation in Minnesota and then to the Puyallup reservation in Washington State, eventually he worked at Carlisle Indian School in Pennsylvania, and from Carlisle he came to the Pine Ridge reservation. Walker remained at Pine Ridge for the duration of his career, until reaching the mandatory retirement age of sixty-five in 1914. ${ }^{57}$

As medical officer in charge, Walker dedicated himself to counteracting a disease that was threatening the very existence of the Oglala people. Deeply aroused by this humanitarian impulse, in 1897 Walker petitioned the Indian Service for the services of an assistant physician. This was necessary, he advised, so he could concentrate his energies on treating the reservation's exorbitant number of tubercular cases, which extended to approximately one-half of the Oglala tribe. ${ }^{58}$

Reporting a sufficient case load to justify employing six or seven doctors-not just the two allowed-Walker seized upon a rather unconventional approach to confronting the disease: he courted "the cooperation of the local medicine men" at Pine Ridge. But Walker's tactic was apparently not as open-minded as it seemed. While he did want to elicit the support and assistance of Oglala shamans, and even adopted and 
utilized some of their psychological methodology—particularly their powers of suggestion - his real objective had been to undermine their influence. According to Don Southerton, who has chronicled Walker's activities, the doctor "reported building friendships with the elders by 'praising the good they did, supplying them with simple remedies and instructing them in their uses ... privately ... [he] charged them with their trickery and persuaded them to abandon such methods." Although his purpose may have been to undercut the authority of Oglala healers, when the nature of his actions became known, missionaries on the Pine Ridge reservation complained to the secretary of the interior, alleging violation of the federal Indian policy of assimilation. An investigation eventually absolved Walker of wrongdoing, but in the opinion of Southerton, the doctor's capacity to combat tuberculosis was diminished. ${ }^{59}$

Walker, no different than Indian Service personnel from across the country confronted with the insidiousness of tuberculosis, determined that drastic steps needed to be taken if lives were to be saved. One likeminded official was Edwin L. Chalcraft, the superintendent of Chemawa Indian School in Salem, Oregon, at the same time that Walker was serving at Pine Ridge. Mirroring the situation at Pine Ridge and conditions elsewhere, infection rates at Chemawa were exploding off the charts, a harrowing state of affairs that spurred Chalcraft to action. In response, he devised an open-air treatment for consumptives that began as a tent colony in the spring of 1907 and quickly evolved into permanent wards made up of sixteen wood-frame cottages, eight each for girls and for boys. As Chalcraft described them, these structures were sixteen feet square "with polished floors 2 feet from the ground; hip-roofs with a large glass skylight on the south slope; and enclosed with walls all around to within 3 feet of the roof, canvass that could be rolled up enclosed the space between the siding and lower edge of the roof. The buildings were heated by steam and lighted with electricity." Of those students who underwent his method of treatment, Chalcraft boasted, not a single one died. ${ }^{60}$ 
As Chalcraft was busy on the Pacific Coast, Walker was active at Pine Ridge. To provide comprehensive care and check the spread of the disease, Walker, like Chalcraft, proposed the construction of a tuberculosis sanitarium. His plan called for a tent camp-not unlike that of Chalcraft's initial invention-laid out over four sections. Walker believed that this would enable him to begin to get a handle on the 539 diagnosed cases of tuberculosis on the reservation. He suggested starting in an economical manner, apportioning one tent for every two patients, while requisitioning funds for a kitchen and a dining room, a laundry, a warehouse, a barn, outhouses, employee housing, and fencing. The tents, measuring twelve by fourteen feet, would be furnished with a single bed, a chair, a drinking cup, a washbasin, a cuspidor, and a chamber pot for each occupant as well as a camp stove, a water bucket, a pitcher, a slop pail, a washstand, and a lantern. ${ }^{61}$

Walker requested a staffing allowance of a physician in charge, a cook, a laborer, a laundress, a nurse, and a matron, with the laborer being accorded police powers. Fresh food, a necessity in treating the ill, would be supplied from beef cattle, milk cows, and chickens. A farmer equipped with a work team, harness, wagon, agricultural implements, and seed would provide for the cultivation of the fields. Walker estimated the overall cost "at between three thousand and thirty thousand dollars 'depending on the quality and completeness of the plant."'62

In the summer of 1908, Walker forwarded to Francis E. Leupp, the commissioner of Indian affairs, a draft of his proposal, but he was to be disappointed in the reaction it received. Leupp had visited Chemawa Indian School, observed the wooden buildings raised by Chalcraft, and endorsed the school superintendent's approach. Thus, when the commissioner reviewed Walker's documents, he responded only by furnishing the Pine Ridge physician with a set of the blueprints drawn up by Chalcraft in Oregon. Walker's dissent was apparently grounded in the frigid South Dakota winters and the havoc they could-and were likely-to wreak on tent life. ${ }^{63}$

Failure to authorize a tuberculosis sanitarium was emblematic of 
the national government's piecemeal response to meeting the essential health care needs of the Oglala people. For a span of nearly two decades following the retirement of James Walker, the level of services and the quality of facilities dropped relative to the number of tribal members positively disposed toward receiving treatment. Increasingly, the Oglalas found themselves in closer and more frequent contact with nonIndians and further alienated from traditional methods and life ways, intensifying the potential for health problems and disease while heightening the stresses placed upon available medical supports. But as the number of Lakota seeking assistance soared, the ability of the reservation's medical staff to satisfy that demand at best remained static and at worst declined. The result was a threshold of suffering and morbidity that exceeded anything experienced previously.

A landmark event in the evolution of health care at Pine Ridge occurred in 1912. Automobiles that year were acquired by the agency for the first time-one for each of the two physicians on the reservation. According to Superintendent Brennan, the cars constituted a boom, greatly enhancing the efficiency of the doctors by making it possible for them "to cover a great deal more ground than" before. With that benefit in view, Brennan pressed the Indian Office for the funds to purchase an additional vehicle to be reserved for a third staff physician. "These machines," when "supplemented by horses for very bad weather and times when the machines are out of commission," he purported, significantly "extend the field of the physicians and give much better returns in service for the money expended." 64

However, as always seemed to be the case at Pine Ridge, gains could be fleeting. Four years later, Superintendent Brennan apprised the commissioner of Indian affairs that there was only a single automobile at his disposal for medical purposes. He requested two more, one less than an inspecting officer who lobbied for a third additional vehicle. According to Brennan, the physician at Kyle was driving his own car, "an imposition," and he reiterated his earlier assessment of the efficiency of motorized transportation: it "more than doubled the capac- 
ity of the physicians to make calls, in this country of great distances." By 1921, the agency had been equipped with a fleet of three Ford touring cars, modern assets that were enabling the reservation's three physicians "to do much more effective work than heretofore." 65

And that was followed by an even greater breakthrough. Of incalculable importance and another milestone in the history of the Pine Ridge reservation was the opening of a new hospital at the boarding school in 1914, replacing a structure that had been continuously in operation for twenty-two years. Unfortunately, this hospital—of all brick construction and supporting twenty-one beds-remained the only medical facility on the reservation, a deficiency that required the one physician on staff to fulfill, as best he was able, the health care requirements of the entire Oglala population. An unsatisfactory if altogether impossible situation, it inspired Brennan to launch a spirited, although in the short term ineffectual, campaign to have a general hospital built. "It is reported that a new hospital is to be constructed on this reservation in the near future," he wrote encouragingly to the Indian commissioner in 1914, "and I earnestly hope that this dream will come true, as such an institution is badly needed." He reminded his superior that there had been agitation from him and from others for a number of years, and a site for either a hospital or a sanitarium had been "selected and set aside nearly ten years ago for this purpose." 66

Unquestionably there was ample justification for going forward with a general hospital on the reservation. As one indicator of the rising interest in services, a tent colony was set up on the boarding school grounds in the summer of 1914. Several Oglala families took this unprecedented step in order to avail themselves to "the benefit of constant treatment" from the school hospital. In response, Superintendent Brennan mulled over the prospect of establishing "a permanent camping place for such purposes near the agency." As he saw it, the only drawback was the potential for abuse if "not closely watched." The Oglalas, he cautioned, "would like nothing better than an excuse to camp near the agency, leaving their allotment and gardens." 67 
While the Oglala Lakotas were proactively taking matters into their own hands, Brennan offered the perceptive comment that the principal threat to health on the reservation was not epidemics but too few physicians to treat "the ordinary run of sickness." Although a staff of three doctors was budgeted for the reservation, typically only one or two of those positions were filled at any one time, and sometimes there was not even that level of support. Significant blame for that situation rested with Pine Ridge. For Indian Service personnel it was simply not a coveted appointment. In his 1914 annual report, for example, Brennan lamented that the physician's position had sat vacant for "practically the entire year." The office was "very hard to fill and keep filled," he explained, because "whenever an appointee reports for the position, he is no sooner on the ground and started than he is offered a position at increased salary at some other agency and, naturally, he accepts and moves on," leaving "the entire district on the reservation without proper medical attendance." 68

A related issue was the competency and experience of Indian Service physicians. The constantly revolving door of personnel caused some tribal members to come to the understandable conclusion that the reservation was simply a testing ground for the young and a haven for the incompetent. Without doubt the quality of staff posed an ongoing concern, for both the Oglalas and the federal government, and even a brief survey of staff assigned to Pine Ridge lends credence to some of the Indians' suspicions. Take, for instance, the year 1916, when there were three physicians on the reservation. The first, located in the village of Pine Ridge, was thirty-two years old. He had been in the Indian Service for several years, possessed a reputation as being "energetic," "willing," "interested in his work," and for "never refusing calls." His specialization was internal medicine, and he also performed surgeries. "Well liked by the Superintendent, employees and the Indians," he had been slated to assume charge of the general hospital had it been built while he was there. The second doctor was twenty-five years old and a recent graduate of a medical school in Philadelphia. His back- 
ground encompassed seven months of private practice and one year of hospital service. He was said to be "well prepared ... active ... and doing good work" at his duty post in Manderson. Finally, the last physician was "considerably over" fifty years of age. A longtime employee of the Indian Service, he did "not pretend to be thoroughly up to date in medicine," but his superiors believed he was trying his best to meet the needs of his patients. According to Indian Service records, he was "well liked by the Indians and whites in the community" of Kyle. Considered collectively, then, and at this single snapshot in time, all three physicians were seemingly popular on the reservation, but one possessed very limited experience and another was not current on the latest medical practices. ${ }^{69}$

In every way possible, Superintendent Brennan applied pressure on the Indian Office to beef up the level of staffing, particularly in the area of doctors. In 1910 he reported that "it is impossible for four physicians to cover the entire reservation-comprising four counties"; in 1912 he said: "The reservation is so large and the population so scattered that the number of physicians is entirely inadequate to give the proper attention to the cases arising which call for practice on their part. There are practically seven thousand people scattered over an area ninety miles long and sixty miles wide"; in 1914 he expressed relief that "there have been no epidemics during the past year, merely the ordinary run of sickness. Our principle trouble has been the lack of physicians to handle the routine business." And so it went. But the national government, in failing to develop sufficiently the medical infrastructure at Pine Ridge, was flirting with disaster in the advent of an emergency. ${ }^{70}$

The staffing issue reached a flash point in the fall of 1918. That year the worldwide influenza epidemic raged across the reservation, unleashing in its wake unprecedented sickness and death. Undoubtedly there would have been some loss of life no matter what preparations had been made, but at Pine Ridge the medical corps was wholly illequipped to respond to the health crisis that ensued. In 1918 there was no agency physician employed on the reservation, only one doctor as- 
signed to the boarding school and another stationed at Kyle. The school physician had responsibility for 250 boarding students, a like number of students enrolled in Holy Rosary Mission four miles north of the village of Pine Ridge, and approximately one-half the remainder of the general reservation population. The doctor at Kyle maintained oversight over all day school students and the other half of the reservation's adult population. ${ }^{71}$

Partly due to the deficit in medical personnel, circumstances deteriorated rapidly in the days after the scourge hit. The physician at Kyleand his entire family — were "among the first to contract Influenza," an initial strike that debilitated him to an extent that he was able to provide no more than minimal assistance "during the worst part of the epidemic." Meanwhile, the physician in charge of the boarding and mission schools thought to take the extraordinarily farsighted step of quarantining each of his campuses, a directive that was kept in effect throughout the ordeal. At the height of the outbreak some 3,500 Oglalas were stricken, and by the time it had finally run its course, an estimated 350 to 400 had died. It is noteworthy, however, that no fatalities were reported among boarding and mission school students, and in the aftermath of the tragedy, the agency superintendent felt compelled to issue the telling statement that while it was a fact that "the deaths... could not" have been "prevented," it was also true that "the one physician could not cope with the situation." 72

In the spring of 1922 a less virulent strain of influenza passed through the reservation. There were no fatalities, but the 168 cases diagnosed in the boarding and mission schools underscored the essential need for increasing the number of medical doctors on staff. Similar to the composition of the field staff in 1918, only a single physician was servicing the village of Pine Ridge, and with the care of students monopolizing all of his time, no time was left "for reservation practice," the most glaring neglect occurring in obstetrical cases, virtually all of which were going "unattended by physician." Influenza struck again the following spring, causing several deaths, and in 1927 outbreaks of 
whooping cough and red measles proved "serious and far reaching," producing "a great many deaths among the infants and children under three years of age." 73

And there were lingering threats. In 1919 the agency superintendent reported that the purity of the water had not improved, triggering a few mild cases of typhoid fever among boarding school students. Without swift and substantial intervention undertaken by the Indian Office, the agency physician worried that a "disastrous" epidemic might occur. The decades-old problem persisted that the water that supplied both the agency and the boarding school fed directly from White Clay Creek to the standpipes and from those to the consumers without filtering. The superintendent conjectured that "since the creek is not a very large one" and was "used as an outlet for refuse, as well as watering stock," it was only a matter of time before it became polluted "to such an extent as to be injurious" to the health of children and agency employees. In order to supply potable water to Pine Ridge, the superintendent recommended drilling several deep wells "at an early date." In this instance the national government reacted swiftly. Pipe was sunk the next year. ${ }^{74}$

But the health of the Oglalas was trending downward. In 1922 the agency superintendent offered an unusually candid, pessimistic assessment. “There are, without doubt," he feared, "considerable numbers of cases of tuberculosis and other diseases which are wholly without treatment, save such aid as the Indians themselves may provide." In terms of tuberculosis, so little was being done that most of the infected were receiving no medical assistance whatsoever. Fault lay not fully with the national government; the Oglalas often declined treatment. But more often than not, there were no services to turn down. According to the superintendent, the only effective method of treatment was sanatoria hospice, and patients had been referred to facilities located in Iowa and Idaho, but that option was not always feasible. "The distance of these institutions from the Reservation, coupled with the reluctance of the Indian people to leave their homes during illness, and the shortage of 
funds for such purposes," the superintendent reported, had limited the number of patients he had been able "to send away." Lauding the remarkable results attainable through sanatoria care, the superintendent pleaded with the Indian Office for the construction of such a resource on the Pine Ridge reservation. It was their sole hope, in his view, for arresting the disease and saving lives. ${ }^{75}$

In 1923 the agency superintendent reported that proposals for both a general hospital and a tuberculosis sanatorium had been submitted. It had been suggested that the sanatorium be located "somewhere in the Black Hills," described as "a sort of Mecca for all Sioux." The sanatorium initiative failed to garner BIA approval, however, and an application for a general hospital was substituted in its place. But that request did not go without opposition. "There are many objections to a local hospital," the agency superintendent explained. "The expenditure of money would be considerable, and it appears that more real service could be given the Indians if a similar sum were expended in increasing the number of physicians on the reservation. Such a plan would limit the territory of each physician, thus giving him time to actually cover his district." He urged that whichever arrangement was finally adopted be put "into practice as early as possible, since the health conditions on this reservation are not at a desirable standard." Several years later, another superintendent went further, recommending approval of a general hospital consisting of 200 to 250 beds. $^{76}$

The problem was two-fold. More students required sanatoria care, and across the reservation more Oglalas required hospital services, than could be accommodated. In both instances, funding and facilities were inadequate to meet need. And even when there were open beds in the school hospital — which was actually often the case — government officials were wary of filling them with nonstudent patients for fear space would be unavailable in the advent of an epidemic. Due to the highly communicable nature of tuberculosis, placing tubercular patients in the school hospital was not an option either. The longstanding solution of local officials was the construction of either a sanatorium or a 
general hospital open to all members of the reservation community, whether infants, very young children, adults, or students.

By any standard the reservation was wracked with disease, which was at once partially a result of and made worse by another hard truth: a widespread prevalence of malnutrition. In the first decades of the twentieth century the Oglalas continued to subsist largely on government rations, provisions that afforded an unbalanced diet heavy in meat (mostly beef) and starchy dried goods but that was light in fresh fruit, vegetables, and dairy products. Besides the lack of variety contained in the food, the distributions to families were insufficient. In tandem, the dual factors of quality and quantity contributed to an ongoing health crisis among the Oglalas.

Hunger posed a gut-wrenching reality. A survey of reservation conditions conducted in 1925 revealed "beyond a doubt that many Indian families" went "for days at a time with the scantiest food supply." According to this study, "many homes were found where the only article of diet was beans; others were found where horse meat and cattle meat in a questionable state, was the dependence until the next ration day. Many families were found who had been without flour for several days. Other instances were encountered where bread and coffee appeared to be the sole diet." The agency superintendent admitted that "a detailed account of just what the Indians lived on last winter, would not be appetizing. There were probably no cases of actual starvation, but the numerous conditions arising from lack of sufficient food, were clearly in evidence." There could be "but little doubt," he asserted, "that the high infant mortality" - statistics indicated that nearly 25 percent of Oglala babies died before reaching the age of three-was "due to deficient nutrition." ${ }^{77}$

According to almost every commentator on the subject, the precarious state of health on the reservation was directly attributable "to the economic condition of the Indians." In the first decades of the twentieth century, disease and sickness were visible everywhere. Some 30 percent of the Oglala population was infected with tuberculosis, and 
the death rate resulting from the contagion hovered at four times the national average. Another 13 percent suffered from trachoma. A large number of children evinced evidence of "diseased" tonsils, adenoids, and noses that required surgical attention, and "practically every Indian on the Reservation" was "under nourished" and without other necessities such as soap and clean water. Only "one family in twenty" owned "a milk cow" and not more than one percent of families had milk to drink on a regular basis. The average Oglala family comprised ten members living in a one-room log house that was ten by sixteen feet in size, dirt floored and dirt roofed, and poorly lighted and ventilated. Many Oglalas ate and slept on the bare floor, hauled their cooking water in barrels, and were without bathroom, bathing, or clothes-washing facilities. So alarming grew the reports of deprivation and want that a delegation of the American Red Cross was dispatched to investigate. ${ }^{78}$

Documentation of the extreme socioeconomic conditions, together with the lethargic response of the Indian Office to do much of anything about it, and in tandem with the publication of the Meriam Report in 1928, which spotlighted public attention on the appalling conditions that existed at Pine Ridge and throughout Indian country, resulted in positive intervention finally being undertaken to alleviate suffering and improve the health of the Oglala people. In the late 1920s the national government reinstituted the field nurse program that long had been inactive on the reservation. One nurse was assigned to each of the four outlying districts of Oglala, Allen, Manderson, and Porcupine. In addition, a women's auxiliary was organized to gather, study, and disseminate information related to home and family, and the allowance of physicians on the reservation was increased to five. Other measures were also introduced, including a home construction program, a schedule for administering routine vaccinations, and a comprehensive system for testing the agency's water supply. As a result, agency officials were able to profess, and with a degree of sincerity, that the health of the Oglalas, while far from optimal, was improving. ${ }^{79}$

Much of that positive momentum revolved around the realization of 
a coveted and long-held objective. On January 25, 1931, fully seventeen years after Superintendent Brennan had first raised the issue with the BIA, the following telegram arrived at the desk of the commissioner of Indian affairs: "TWO FLOORS OF NEW HOSPITAL IN OPERATION TWENTY NINE PATIENTS ONE NEW BABY ONE MAJOR OPERATION." The forty-seven bed general hospital was a three-story yellow brick structure built on a hill about a quarter of a mile north of the agency buildings on a location that, ironically, was the former site of an Oglala burial ground. Human remains were unearthed there during the excavation for the basement of the building. The hill on which the hospital sat held other historical ties as well. It was said to have been the scene of one of the last military engagements to take place between the Oglala Lakota and federal troops. Lakota warriors reportedly had used it as a staging area from which they attacked a group of Pine Ridge agency scouts in 1890 . Seven years later, in 1938, another health highpoint occurred when Sioux Sanatorium opened on the former campus of Rapid City Indian School. Although located a considerable distance north of Pine Ridge, it would serve as the primary critical care center for many of the reservation's tuberculosis cases, a function it still performs today. ${ }^{80}$

Despite the obvious advantages attained through the construction of a new general hospital and the opening of a tuberculosis sanatorium, the Great Depression years proved especially challenging for the Oglala Lakota. So extreme grew the hardships and suffering that many children, simply in order to receive the provision of food, clothing, and shelter, were enrolled in the thirty-one day schools and one boarding school in operation on the reservation. Insight into this distressing period can be gleaned from the Depression-era diaries of Marion Billbrough Dreamer, who was an elementary school teacher on the Pine Ridge reservation from 1932 to 1942. During that span she taught at Day School Number Five (also known as Lone Man Day School) near Oglala and at Grass Creek Day School near Manderson. A recent graduate of Washington State College (now Washington State University), Dreamer applied for and received an appointment at Pine Ridge, 
stayed for ten years, married an Oglala Lakota man, and ultimately left deeply disillusioned. Underlying her dissatisfaction was what she believed was an overtly controlling BIA (apparently in its relations with both Indians and agency employees) and frustrations that arose from having to deal with an impenetrable "reservation bureaucracy." The depth of her unhappiness eventually compelled her to terminate her relationship with the Indian Service. ${ }^{81}$

Dreamer's primary responsibility was teaching, but long distances, bad roads, and limited transportation caused her to expend considerable time and energy tending to the health needs of her young charges and their families. According to Laura Woodworth-Ney, who has published excerpts of Dreamer's diaries, Dreamer “accepted her unofficial role as a nurse, observing the health of her students carefully and intervening when she deemed it necessary." At times the obstacles she confronted, which extended beyond simply those related to a depression economy, appeared overpowering. As Woodworth-Ney has documented, "General poverty, undernourishment, and wretched sanitary conditions contributed to a high incidence of infant mortality [on the reservation] and an alarming frequency of communicable disease," including trachoma and tuberculosis. ${ }^{82}$

Because Dreamer was often the only official on hand capable of rendering medical assistance, she had to be prepared to meet almost any exigency. Among the more routine were requests for her to transport adult tribal members to a medical doctor or a medical facility. As a day-school instructor having access to an automobile, she was able-and with the generous and substantial assistance of her husband - to accommodate most of those seeking aid. For example, when one Oglala man complained that his wife had been suffering with her teeth for two weeks, George Dreamer agreed to drive her to a dentist in Chadron. Similar trips were undertaken into the village of Pine Ridge. Sometimes it was for purposes related to health care, at other times to pick up groceries and supplies, and on occasion to conduct pressing business. ${ }^{83}$

In a majority of instances, however, Dreamer was on her own to ad- 
minister treatment. From nursing earaches to furnishing baby powder and salves to dispensing medical advice, Dreamer was involved, directly and often profoundly, in delivering health care to those around her. Woodworth-Ney related a situation that occurred in April 1937. A student of Dreamer's fell ill, giving "out by noon" each day for several days in succession. The teacher responded by sending the student and her sister home before school was out for the day. Outwardly concerned, Marion and George Dreamer, in an attempt to urge the mother to take the sick child to the hospital, drove out to the house where the girls lived. The advice given operated to good effect, and the Dreamers accompanied the family into Pine Ridge, but when they got to the hospital a doctor could not be roused, and to her great dismay, Marion Dreamer observed the other sister (who had been in the hospital the previous week) "running around with out any shoes." In the end, all the efforts of Dreamer and the afflicted girl's parents had no effect, as the condition of the sisters continued to deteriorate. In her diary, Dreamer lamented the family's "desperate circumstances." There were "two beds for nine of them with hardly any bedding," and "Today Irene is just as tired out as Mary Rose. She has sit around the school house all day." $\$ 4$

That same month another student's health teetered so precariously on the brink that the Dreamers felt they had no choice but to take decisive steps to ensure that prompt attention was given. Marion Dreamer described the situation in her diary. "All the children except Katherine Kindle are in school again," she wrote. "Her sister told me yesterday that she was sick and did not seem to get any better. She has been sick for three weeks. George took her to the hospital to-day and the doctor kept her there." 85

Sickness and disease exacted a toll on school attendance, and the number of children sitting in class on any given day served as a fair barometer of the state of the health of the student body. Trachoma, a serious infection of the eye that without proper treatment could lead to blindness, was a common ailment. Woodworth-Ney explained, "Doc- 
tors periodically conducted examinations at school, usually sending those who needed further treatment to the hospital." But that was not always possible, and Dreamer never forgot one especially horrific scene in which a visiting physician "laid the children on a table, held the eyelids back and scraped them with a sharp knife." ${ }^{\prime 6}$

Death posed another inescapable reality. Statistics are hard to come by, but average lifespan of the Oglalas was in all likelihood considerably below the national average, while rates of infant and child mortality were in turn substantially elevated. Dreamer documented one four-day period in 1937 during which three deaths occurred. Two were of infants, and the Dreamers were involved in the funeral preparations made for them. Marion Dreamer wrote in her diary: "Mrs. He Dog died, Geo took Willie to Pine Ridge to get things for the feast. The Little Brings Him Back baby died too. Geo began digging the He Dog grave." A few days later, Dreamer added that "Geo went to McKinley Slow Bears to take his little baby to the cemetery. It is about a month old and died last night. It was buried in the Catholic Cemetery at Oglala. They took it in the back of the car." ${ }^{87}$

Sometimes illness and death struck with such dual ferocity that parents had to make the unfathomable choice between attending the funeral of a child or expending their energies trying to procure treatment for the living. This was the heartbreaking dilemma that confronted the Slow Bear family. Dreamer recorded that she had had to excuse two of the Slow Bear daughters from school so that they could "take care of their younger brother while their father was at the cemetery." According to Dreamer, "Mrs. Slow Bear did not witness the burial of her baby ... because 'she had to take another sick child (Rose Mary) into the hospital." Of course, the most trying for Dreamer were those times when one of her own students passed away. One instance of this occurred when an entire family of school-age children had to be kept home because of tuberculosis. Dreamer subsequently learned from a relative that one of the girls had succumbed to the disease. ${ }^{88}$

As revealed in the experiences of Dreamer, Pine Ridge presented a 
brutally demanding environment that seemed little changed since the creation of the reservation. In 1950 the federal government conducted a survey of health and living conditions, and the findings duplicated decades of federal agency reports, providing a stark indication of what Robert Ruby was to confront in his duties as medical officer in charge. At midcentury, 6o percent of families continued to live in log houses. Tuberculosis, malnutrition, pneumonia, dental caries, measles, conjunctivitis, and scabies remained the primary risks to health. Potatoes, rice, macaroni, and other foods high in carbohydrates and low in protein were the principal diet. There were only four physicians on the reservation in addition to one director and one assistant director of nurses supervising a staff of seven nurses. Perhaps more telling, of a reservation population that had grown to nearly eleven thousand, only thirteen tribal members were college graduates, and almost 20 percent of children between the ages of six and eighteen were not enrolled in school. Average annual family income was placed at $\$ 1,290$, less than a quarter of the national average of $\$ 4,237$ and a figure rendered even more troubling when it is factored in that average family size was at least double at Pine Ridge to that of the national average of three per household. ${ }^{89}$

If gains had been made anywhere, they were in infrastructure. By 1953, when Ruby located to Pine Ridge, a complex system of hospitals and other health care facilities was under operation of the BIA. Across the continental United States and Alaska, there were sixty-two hospitals and three tuberculosis sanatoria. The largest of these, having a capacity of between 150 and 425 beds, were classified as "medical centers." The others were termed "general" hospitals. Most were relatively small, servicing on average fewer than 50 patients per day. During Ruby's tenure, Pine Ridge functioned as a modern, comprehensive, medical-surgical general hospital with a bed capacity of 46 , one of the largest of ten medical units under Aberdeen Area jurisdiction. It supported a clinic, an emergency room, an ambulance corps, and a pharmacy, and it also maintained dental, optical, and pediatric departments. In fact, 
such was the diversity and range of services available at Pine Ridge, other BIA hospitals in North and South Dakota were under direction to transfer their elective surgeries there. In Ruby's estimation, the care patients received was probably "equitable to that of most of the small town hospitals of the time." He believed that they "didn't lack for much," as Pine Ridge possessed "most of the apparatus that was just beginning to come available to keep people alive." ${ }^{90}$

While Ruby was there, Pine Ridge Hospital teemed with activity. Some 1,400 patients were admitted annually, on average just under 4 per day. In a given year the hospital experienced 210 births and 30 deaths. The surgical unit performed about 20 operations per month. Five doctors were on staff, or at least that was the number budgeted for. In addition to Ruby, who simultaneously held the positions of medical officer in charge, orthopedist, and surgeon, there were four others: an ophthalmologist, an obstetrician and gynecologist (who was also the anesthesiologist), a pediatrician, and an internist. Rounding out the hospital's personnel were one dentist, nine registered nurses, three practical nurses, eleven blue girls or housekeepers, one X-ray technician (who in addition performed all lab work), two medical clerks, and four janitors. ${ }^{91}$

But these positive developments masked serious, fundamental problems churning just below the surface that were verging on bringing about a complete re-organization and re-alignment of Indian health care. A great value of the Ruby letters is their on-the-ground documentation of a national Indian health care system in crisis, a system that had atrophied and was languishing in its final throes. The year and a half that Ruby was at Pine Ridge coincided with the transfer of Indian health care from the BIA to the Public Health Service, a transition that took effect on June 1,1955 . In part, the shift emerged out of a termination-era ethos that sought to assimilate Indians into the mainstream and lessen federal involvement in Indian affairs. A larger point, however, was the unavoidable fact that under BIA supervision Indian health care had been inadequate if not an abysmal failure, the germs of which 
were dramatically in evidence at Pine Ridge and contributed to the frustration and cynicism that came to jade so much of Ruby's outlook. The BIA lagged far behind the armed services, the Veterans Administration, and the Public Health Service in recruiting and retaining physicians. Bluntly put, the BIA health service suffered from a chronic case of the "unders": It was underfunded, understaffed, and under-equipped. According to James R. Shaw, the first director of the Indian Health Service, under the Bга, "The pay was terrible, the doctors were isolated, they had bad facilities, no continuing medical education, and worst of all, they were subordinate to the local BIA superintendent." 92

In comments suggestive that Ruby's was not an isolated experience, Emery Johnson, another Indian Health Service director, described the brief time that he spent working as a physician for the BIA:

After finishing my one year rotating internship, I started at White Earth, Minnesota on June 30 1955, the last day before the transfer. I found that a new stove that had been ordered for the medical officer's residence had been "requisitioned" by the BIA Superintendent, the official "boss" of the reservation. For most of my time at White Earth I was the only physician; we had to go 25 miles to make a long distance telephone call. When I got there I was immediately inundated with patients with eclampsia, motor vehicle and gunshot trauma, diarrheal dehydration, appendicitis, and pneumonia. The stove was not all that was missing from my quarters. There was no laboratory equipment, even for hemoglobin determinations. Most of my surgery was performed with local nerve blocks, but I also used spinals, or drop ether. ${ }^{93}$

The most immediate cause of the transfer, however, was the incontestable reality that the BIA had fallen devastatingly short in its charge to raise the standard of Indian health to a level commensurate with that of the rest of the American population. Statistics compiled on Indian health speak for themselves. During the period that Ruby administered Pine Ridge Hospital, life expectancy for Indians floundered nine years lower than the national average. Infant death rates-among health pro- 
fessionals "a seminal indicator of health status"_— "were nearly three times higher than among other races, and a quarter of all deaths occurred among infants under one year of age." In addition, “maternal deaths associated with childbirth were also three times higher than among whites," while the rates of death "from diarrhea and dehydration were 300 percent higher among Indians.” Impossible to ignore was the fact that 10 to 25 percent of the Indian population remained infected with tuberculosis, an alarming figure which in the years during and immediately after World War II formed the basis of a national scandal and served as a potent symbol of the shortcomings of the BIA as a purveyor of health care. According to one study, the health of the American Indians lagged "approximately three generations behind the rest of the country, due primarily to culture, language, and attitudinal problems, as well as economics, isolation, and above all, lack of service" (editors' emphasis). ${ }^{94}$

It was in this context that Robert Ruby toiled on the Pine Ridge Indian Reservation and constructed the contents of his memoir. Originally written in the form of a series of letters addressed to his sister, they present a first-person account of many subjects condensed into a single volume. Ruby's observations of government practices, medical care, and physical survival convey a sense of how the BIA functioned in the mid-twentieth century while offering glimpses into the rigors and hardships of daily life in Indian country. The book is also a narrative of one man's experiences as a new member of the medical profession, and it is a chronicle of his coming to the threshold of a deeper understanding of cultures and circumstances not his own.

As is usual for a memoir, this is a report of observations, perceptions, and experiences more than a critical assessment. Memoirs are written from the perspective of an interested party, leaving the analysis to others, and for the analytic scholar Dr. Ruby's writings contain a cache of documentation. As a participant in the daily operations of the Pine Ridge reservation, he recorded the lives of his patients and the agency staff. Of both, he formed opinions that he willingly shared in 
unvarnished prose often recorded in the heat of the moment and just minutes or perhaps an hour or two after an event took place. Doubtless the views and attitudes of a young surgeon from a white, middle-class background differed substantially from those that might be obtained from an Oglala Sioux living at Pine Ridge in the 1950s. Historians know all too well that sources are complicated, often incomplete, may address only certain aspects of a complex situation, and can express themselves in a manner considered insensitive or even callous when evaluated against modern sensibilities. Dr. Ruby's memoir offers the perceptive reader several complementary views of his time at Pine Ridge, distilling a detailed look at life there and many of the issues that confronted the Oglala Sioux, the BIA, and the management of Indian health care. But it must always be kept in the forefront that it remains the work of a white physician. The hope of the editors is that the publication of this memoir will stimulate others to add to the scope of our understanding of Indian health care and especially those deriving of multiple perspectives, including the Pine Ridge Lakotas.

A casual reader might infer that Pine Ridge reflected a passing phase of Dr. Ruby's life, one that he filed away in a back drawer along with his copies of the letters that he wrote. (In fact, his correspondence sat hidden and untouched for a half century, until Ruby and the editors met to write a brief retrospective of the works of Ruby and his longtime writing collaborator, John A. Brown, for an article that was subsequently published.) Certainly in its final pages the tone of the memoir suggests as much, projecting an impression of impending finality, that Ruby was prepared to walk away and never return. Ruby began writing with an exaggerated sense of cheerful good humor and perhaps naïveté, an attitude that permeates his opening passages: his recounting of his trip to South Dakota and his descriptions of setting up housekeeping in the village of Pine Ridge. By the close of the year, however, the feeling is markedly different: the mood is more somber, the comments are more pointed and biased, and in the end, cynicism and disillusionment pervade. Today, Ruby recognizes in his letters his 
"sometimes intolerance of those Indians there in the early 50s ... [his] frustration for seeing why one could not snap his fingers with an admonishment and expect results ... [his] impatience with slow or in some case [s] no response of change in their ways of living then." But it would be wrong to presume that in December 1954 Robert Ruby had seen the last of Indian reservations or that he had abandoned his interest in Indian people..$^{95}$

In 1955, after having entered into private surgical practice in Moses Lake, Washington, Dr. Ruby maintained a close association with the American Indians, and he gradually developed a second career as a writer of their histories and lives. His first book, which was composed while he was still in Pine Ridge, was self-published, and his labors as a historian evolved from there. Some works were Ruby's alone; others were prepared jointly with John Brown. Except for a book on Columbia River ferryboats and one on prohibition-era bootleggers, the Ruby and Brown scholarship concentrated solely on American Indian history. If the prolific nature of their relationship can be used as a barometer-in forty years Ruby and Brown published twelve books-it would appear that the fatigue Ruby felt at Pine Ridge was only fleeting, and that with the passage of time and with the advantage of distance and the progressive attitudes toward Indians that emerged in later decades, Ruby's opinions moderated as well. His medical career and his life-long involvement with Indians extend beyond the scope of this volume, but his eighteen months in Pine Ridge were not the culmination of a young man's fascination with the West and its people; they were the beginning of a lifetime of historical exploration, scholarship, and service to others. In the same sense that a healer seeks to achieve the wellness of the whole being rather than strictly the attainment of physical health, Ruby was embarking on a pathway at Pine Ridge steeped in people, medicine, and words that has continued to the present. ${ }^{96}$ 


\section{Timeline of Selected Events in the Life of Robert H. Ruby, MD}

1921 Born in Mabton, Washington.

1939 Graduates from Mabton High School and enters Whitworth College in Spokane, Washington, enrolling in pre-med.

1940 Returns to Whitworth College for second year.

1941 Returns to Whitworth College for third year.

1942 Shortly after U.S. entry into the Second World War, drafted into the U.S. Air Corps as a private. University and college students are conscripted into the military, but pre-med majors and those enrolled in some of the sciences are allowed to finish their degrees. In the fall enters the Washington University Medical School in St. Louis, Missouri.

1943 Medical student, Washington University Medical School, St. Louis, Missouri. Graduates in June from Whitworth College based on three years of credits earned at that institution and one year of credits earned at Washington University.

1944 Medical student, Washington University Medical School, St. Louis, Missouri.

1945 Graduates from Washington University Medical School. In July begins required nine-month medical internship in Detroit, Michigan.

1946 Completes internship in Detroit in April. Two weeks later, reports to Fort George Wright near Spokane. Promoted to officer's rank based on medical training. On June 30 assigned to the air base at San 
Bernardino, California, and on October 15 transferred to San Antonio, Texas, for basic training.

1947 On June 5 assigned to Lowry Field outside Denver, Colorado. On July 12 boards the USAT General C. G. Morton to serve in the U.S. Army of Occupation in Japan. Arrives in Seattle on December 16 aboard the USS Mayo and is discharged.

1948 In January travels to Fort Lawton in Seattle to study basic science before taking exams for medical license. In March begins sixmonth surgical residency at the Sugarbaker Cancer Clinic in Jefferson City, Missouri. In October begins year-long postgraduate course in St. Louis for doctors returning from military service.

1949 Completes postgraduate course in June; then begins a surgical residency in the St. Louis County Hospital in Clayton and the Barnes Hospital in St. Louis.

1950 Korean War begins, and national government calls up physicians who have not met the twenty-month service requirement during and after the Second World War. Ruby falls into this category by a few weeks, but draft law allows physicians-in-training to finish their schooling, enabling Ruby to complete his third and fourth years of surgical residency.

1951-52 Continues surgical residency, St. Louis County Hospital in Clayton and Barnes Hospital in St. Louis.

1953 Completes surgical residency on June 30. Returns to Washington State and marries Jeanne Henderson in Spokane in July. Leaves for Pine Ridge, South Dakota, in August as an officer in uniform in the U.S. Public Health Service.

1953-54 Medical officer in charge, Pine Ridge Hospital, Pine Ridge Indian Reservation, Pine Ridge, South Dakota. 
1954 Edna Phyllis Ruby born in Pine Ridge Indian Hospital; Ruby believes she is the first non-Indian birth in the Pine Ridge hospital. Also, publication of his first book, The Oglala Sioux: Warriors in Transition.

1955-91 Surgeon, private practice, Moses Lake, Washington.

1965 Publication of Half-Sun on the Columbia: A Biography of Chief Moses, Ruby's first collaboration with John A. Brown.

2001 Publication of Esther Ross: Stillaguamish Champion, his last collaboration with John A. Brown.

2004 John A. Brown dies.

2009 Robert H. Ruby continues writing historical articles from his home in Moses Lake, Washington. 


\section{Editors' Comment on Editorial Methodology}

The original material consisted of a series of letters from Dr. Robert H. Ruby to his sister, Marion Johnson, using a typewriter and keeping carbon copies for himself, which he preserved. As he began transferring many of his papers to the Northwest Museum of Arts and Cultures in Spokane, Washington, Ruby retained the rights to this correspondence, with the idea that he might want to edit the letters as an account of his experience in South Dakota. The editors met Ruby while writing an article on the historical work of Ruby and his colleague and coauthor, John A. Brown. Following the publication of the article, Ruby invited us to edit his memoir of the time he spent on the Pine Ridge Indian Reservation.

Our methodology has been to edit for clarity and readability, but to retain Dr. Ruby's voice. As written, each letter was self-contained, sometimes with reference made to previous events. The editors removed repetitive sections and sometimes modified wording for clarity. In some instances minor corrections to dates and spelling were made. Editorial comments were intentionally kept separate from Dr. Ruby's narrative, to avoid breaking into it. The historical analysis of the memoir has been confined to the introduction and a brief conclusion written by the editors. Explanatory material about the contents of the memoir has been added in the form of endnotes, again to avoid disrupting the flow of Ruby's narrative.

Dr. Ruby regularly wrote about the persons with whom he worked as well as his patients, freely using their names in his letters. While this is not remarkable in private correspondence, identifying people can 
be problematic and even unacceptable in a book. Most of those mentioned in Dr. Ruby's letters were not elected officials with official lives that they expected to be bared and opened to public scrutiny. The editors decided that it was important to allow private citizens to maintain their anonymity, particularly in those cases where it was deemed reasonable to believe that embarrassment might follow through the disclosure of their identities. Ruby encountered a wide range of persons possessing a great variety of personal and social problems, including substance abuse (mainly alcohol), child neglect, abject poverty, joblessness, demoralization, and out-of-wedlock sexual activity, and his tendency was to record everything that he either witnessed himself or heard about through others. For the sake of privacy, the editors have excised from the text the names of persons who might feel embarrassment, and vague descriptions have been inserted in place of the names. In a very few instances, pseudonyms have been used. The social issues encountered by Dr. Ruby remain serious challenges and ones that the Oglala Sioux Tribe is working diligently to overcome. 


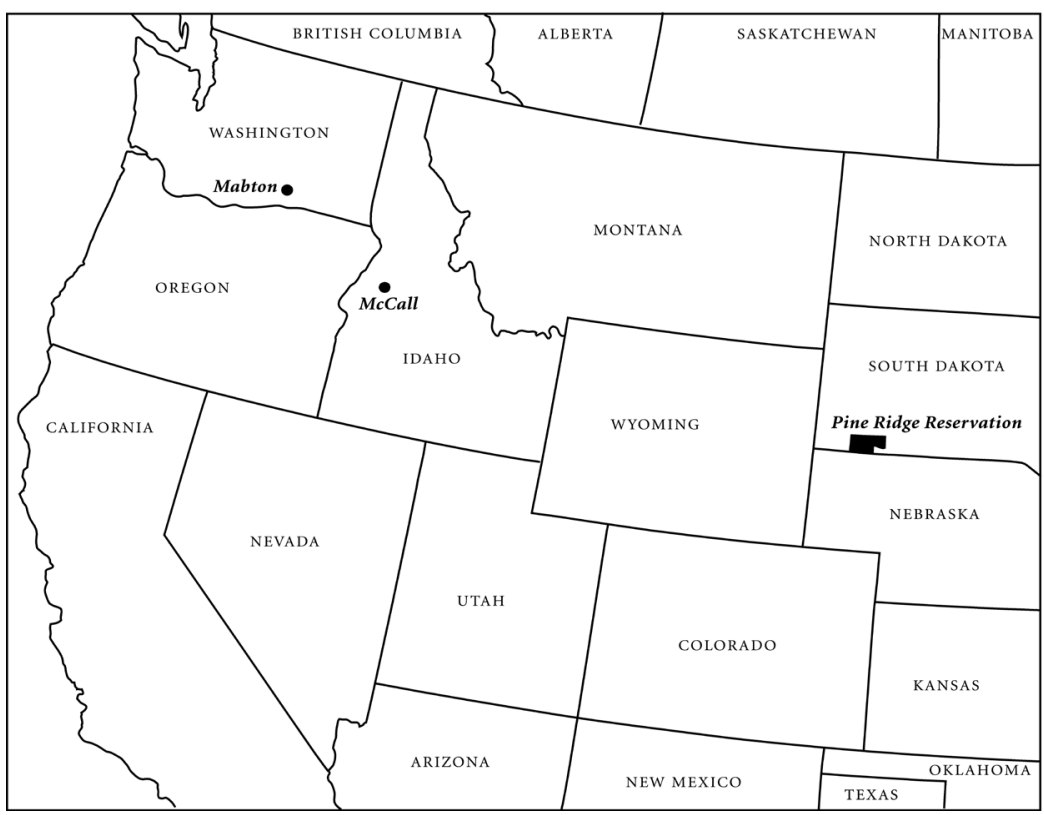

1. Robert Ruby's Northwest. The spatial relationship between Dr. Ruby's childhood home in Mabton, Washington, his sister's home in McCall, Idaho, and the Pine Ridge Indian Reservation in South Dakota. The newly married Rubys drove from Washington State to McCall and then to South Dakota to start their married life and Dr. Ruby's career as a physician and surgeon. 


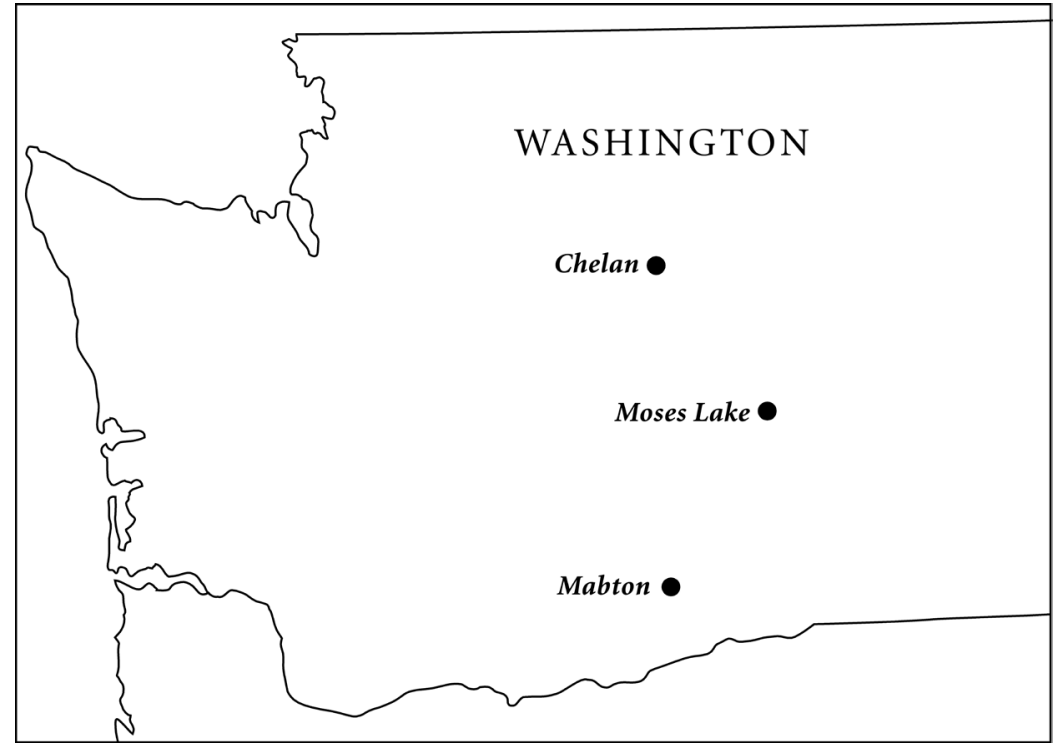

2. The three Washington communities most important to Dr. Robert H. Ruby: Mabton, where he was born and raised; Chelan, his wife Jeanne's hometown; and Moses Lake, where he established himself in private practice in 1955 following their return from Pine Ridge. 


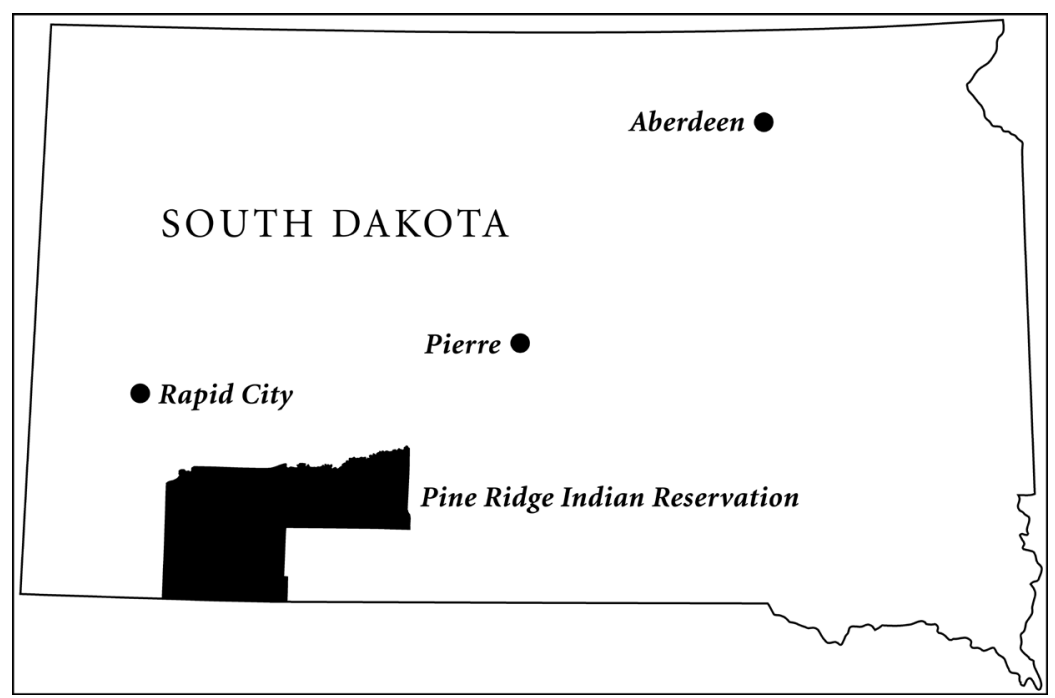

3. The locations in South Dakota most relevant to Dr. Robert H. Ruby: Aberdeen, where his superiors in the Bureau of Indian Affairs were headquartered; Pierre, the state capital; Rapid City, the nearest major commercial center off the reservation, and the Pine Ridge Indian Reservation, where Dr. Ruby worked. 


\section{SOUTH DAKOTA}

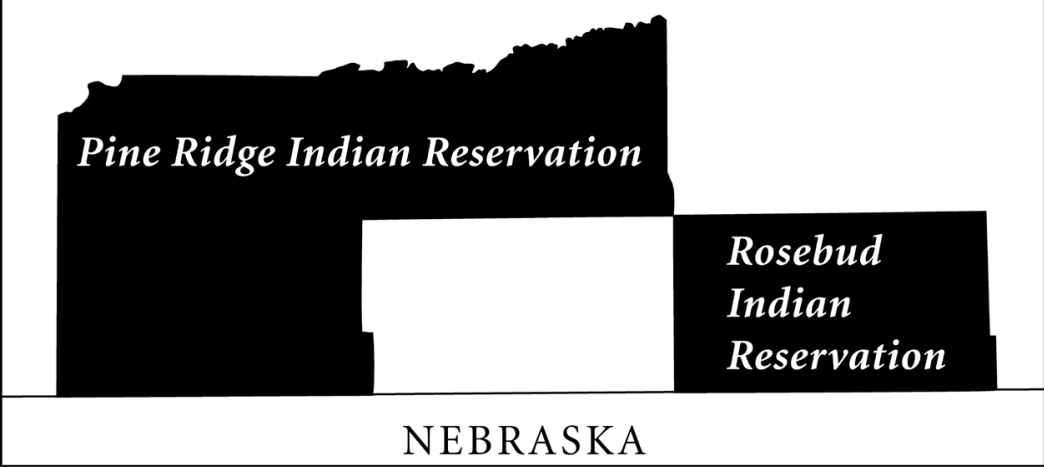

4. Indian Reservations in southwestern South Dakota. The Pine Ridge Indian Reservation and Rosebud Indian Reservation. Dr. Robert H. Ruby was based on the Pine Ridge Reservation, but he and his colleagues worked across reservation boundaries on some occasions.

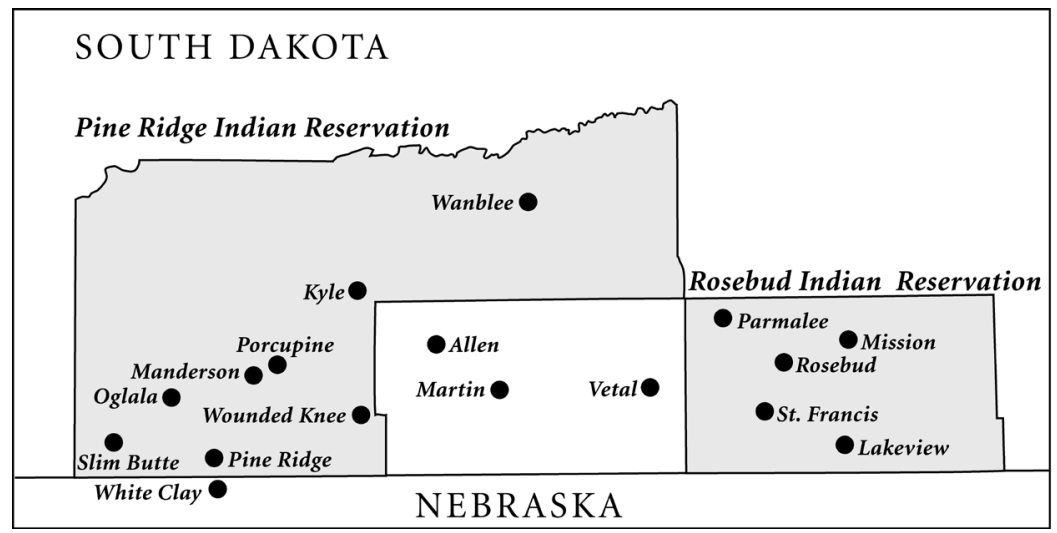

5. Pine Ridge Indian Reservation and Environs. The communities on the Pine Ridge and neighboring Rosebud Indian reservations. Dr. Robert H. Ruby became familiar with the small communities on the two adjoining Indian reservations and neighboring towns during his tenure at Pine Ridge. 